\title{
The grammaticalization of prospective aspect in a group of Neo-Aramaic dialects*
}

\author{
Eleanor Coghill \\ University of Konstanz
}

\begin{abstract}
This paper examines the development of a future (more precisely 'prospective') auxiliary from a motion verb in a small group of Neo-Aramaic dialects spoken in Iraq. The long written record of Aramaic allows us to follow the grammaticalization process in some detail, and recent documentation of dialects has shown that various stages co-exist synchronically. The Neo-Aramaic case challenges the theory that future auxiliaries from a verb 'to go' should derive from an imperfective in languages which have one. The development of the auxiliary also involves the reanalysis of a present perfect as an immediate future: this apparently surprising development is explained and possible parallels to it in other languages given. The prospective construction exists alongside another future tense and the differences in form and function can be seen to reflect the different origins and ages of the two constructions. There are strong indications that the prospective construction has developed as a result of contact with a similar vernacular Arabic construction. The distribution and level of maturity of the construction in the different dialects can be explained by an origin in a village close to the Arabic-speaking area, and thence diffusion to the neighbouring villages.
\end{abstract}

Keywords: grammaticalization, tense and aspect, prospective, future, NeoAramaic, dialectology, contact

\footnotetext{
* The fieldwork on which this paper is based was funded by the Arts and Humanities Research Council, as part of the North Eastern Neo-Aramaic Project at the University of Cambridge. Thanks are due to the many Chaldeans who patiently answered my questions, especially Shawqi Talia, Dinha Gorgis, Mahir Awrahem, Ghazwan Khundy and Father Habib Naufali, to my colleagues Geoffrey Khan, Roberta Borghero and Kristine Mole for sharing their data with me, and to Joe Salmons and Diachronica's anonymous reviewers for their helpful comments. Any mistakes are my own responsibility. The data presented from Neo-Aramaic and Arabic dialects is from my own fieldwork, unless otherwise indicated.
} 


\section{Introduction}

Pathways for the development of future tenses have been extensively studied (especially Bybee, Pagliuca \& Perkins 1991, Bybee \& Pagliuca 1987, Bybee, Perkins \& Pagliuca 1994:243-280). Among the common sources of futures are expressions of desire, obligation, and translocation. In order to test some of the hypotheses that have been made about pathways, detailed case studies are required. Such case studies can be more useful where historical evidence of early stages is available, so that it is not necessary to rely on reconstructions. Because of the long written record of Aramaic, going back 3,000 years, it is possible to examine in detail the precise processes of grammaticalization through which new tenses have emerged, and to test hypotheses that have been made about these processes.

Languages sometimes have two or more ways of indicating future time reference. This could be due either to separate development from distinct sources (such as translocative or desire verbs), or to similar developments which took place at different periods, so that new markers emerge alongside older forms (Bybee, Perkins \& Pagliuca 1994:243). Distinctions between future constructions in their range of usages have been attributed to the relative age of the constructions (Bybee, Perkins \& Pagliuca 1991:26-32): more mature future grams may have late-developing uses that newer future grams lack. Alternatively they might be attributable to the retention of earlier non-future uses, which may vary according to source of the construction. The roles of source and age, therefore, interact in determining the distinctions in functions between future markers.

The North-eastern Neo-Aramaic (NENA) dialects of the Mosul (or 'Nineveh') Plain in Iraq provide a useful case study for understanding the grammaticalization of futures. Most NENA dialects possess a future tense (prefixed with $b$ - or $b$ ad-) derived from a verb of desire. The dialects spoken on the Mosul Plain possess an additional form, with an auxiliary/particle $z i(l)$-, which is derived from a verb of translocation ('to go'). The $z i(l)$ - construction is distinct from the $b$-future, being more precisely termed a 'prospective' (Comrie 1976:64-67), in that it presents a future event from the point of view of the present. One question to consider then is to what this distinction can be attributed. Is it a difference in source (desire vs. translocation), or is it the relative maturity of the two constructions (the desire future is older) and the distance each has progressed along the grammaticalization cline? This is one question this paper addresses.

Another issue concerns the grammaticalization of futures from translocative verbs. These derive from expressions such as 'he is going (in order) to eat', where the main verb is reinterpreted as a future auxiliary. It has been claimed that, in cases of futures derived from a translocative, the verb will be in an imperfective (or specifically progressive) form, or at least a form that covers these functions (Bybee 
\& Pagliuca 1987:116, Bybee, Pagliuca \& Perkins 1991:30). This is supported, for example, by the English going to construction and Kru future auxiliaries, which derive from imperfective forms of a verb 'to go' (Marchese 1986:101). Nevertheless, evidence from the NENA dialects of the Mosul Plain, and possibly other languages, challenges this claim. While the Mosul Plain dialects have a special (relatively new) progressive construction, as well as an older imperfective present, the auxiliary $z i(l)$ - is derived from neither: rather it is identical in form and origin to a construction used to express the immediate future of the verb 'to go'. This construction moreover originally had a present perfect function. The change in function from past time to future time reference is in itself surprising and will be discussed further; the derivation of a future auxiliary from a form with either function would appear to contradict Bybee, Pagliuca \& Perkins's hypothesis. This paper examines in detail the new prospective construction that has developed in the Mosul Plain dialects and its theoretical implications.

\section{The NENA verbal system ${ }^{1}$}

The NENA dialects are spoken in Iraq, Iran, Turkey and Syria by Christian and Jewish communities. They are descended from ancient Aramaic, and as such belong to the Semitic branch of Afro-Asiatic. They show huge diversity, to the extent that varieties are often mutually unintelligible. Significant dialectal differences exist even between neighbouring villages. This variation sometimes reflects the different stages of change in progress.

The dialects have undergone a great deal of innovation in their verbal systems, much of it shared across NENA. The NENA verbal system is built mainly on two bases, derived from earlier active and passive participles; there are also analytical verb forms, less relevant to this paper. NENA has the Semitic triradical root system, where typically each verb lexeme consists of three root consonants. Forms are derived using templates. The template for what is known as the 'past base' is $\mathrm{CCaC}$ - (CCiC-before a vowel), and the template for the 'present-future base' is $\mathrm{CaCC}$-, where $\mathrm{C}$ represents a root consonant of a verb. So for $\check{s} q \mathrm{l}$ 'to take' the past

1. The glossing practice in this paper follows the Leipzig Glossing Rules. Where a stem is glossed with the English citation form with no further annotation (e.g. "eat", "sleep"), it should be understood as a NENA present-future base. For example, FUT-take-3PL (glossing $b$-šaql-i "they will take") is short for FUT-take.PRES-FUT-3PL. Where a stem is glossed with the English past tense (e.g. "ate", "slept"), this should be understood as a NENA past base. Note also that the $3 \mathrm{~ms}$. inflection of the present-future base is $-\varnothing$, and the stem used with it is $C \bar{a} C \partial C$ instead of the suffixed allomorph CaCC-. Such $3 \mathrm{~ms}$. forms are glossed with “.3Ms”, e.g. b-šäqal [FUT-take.3Ms] "he will take" (Compare $b$-šăql- $\vec{b}[$ FuT-take-3Fs] "she will take"). 
base would be šqal- (šqil-V) and the present-future base would be šaql-. (Derived verb lexemes, such as causatives, have different patterns, not relevant here.) The past base is used for the past perfective, e.g. šqal-li "I took", while the presentfuture base is typically used for irrealis, the indicative general present (which covers habitual aspect and the expression of general truths) and the future. In most dialects these functions are distinguished by prefixes: in the Mosul Plain dialects the irrealis functions take no prefix, e.g. šaql-a "she may take", the general present takes a $k$ - prefix, e.g. $k$-šaql- $a$ "she takes", and the future takes a $b a d-\sim b$-prefix, e.g. $b a d-\check{s} a q l-a \sim b$-šaql-a "she will take".

The two bases usually take different subject inflections. The present-future base takes 'S-suffixes' (from 'subject suffixes'), while the past base takes 'L-suffixes' (named after their initial consonant $/ l /$ ). ${ }^{3}$ As these suffixes play a prominent role in the discussion, it is worth elaborating on their derivation. The S-suffixes derive from a merger of the person-gender inflection of a participle with enclitic pronouns:

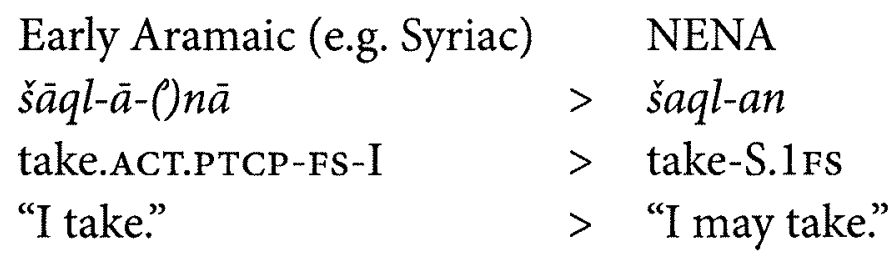

The L-suffixes, on the other hand, derive from an affixing preposition $l$ - "to" plus a pronominal suffix expressing the object of the preposition. The resultant combinations eventually became bound affixes:

$\begin{array}{lll}\text { Early Aramaic (e.g. Syriac) } & & \text { NENA } \\ \check{s} m \bar{\imath}^{-} & l-\bar{\imath} & >\check{s} m e-l i \\ \text { heard.PASS.PTCP } & \text { to/by-me } & >\text { heard-L.1s } \\ \text { "I have heard." } & > & \text { "I heard." }\end{array}$

Other members of this suffix set include $3 \mathrm{~ms},-l a(<l-\bar{e})$, 3fs. $-l a(<l-\bar{a} h), 1$ s. $-l i$ (from $l-\bar{\imath}) .4$

2. The terms for the bases, though convenient, oversimplify the situation somewhat: the "present-future base" is also used in many dialects with a prefix to express a complementary past perfective that takes pronominal object suffixes, e.g. kam-šaql-ä-la [PST-take-she-it] "she took it" (Telkepe dialect).

3. These suffixes will be glossed as " $S$ " and " $L$ " in the examples.

4. See Hoberman (1988) for an in-depth discussion of NENA pronominal suffixes, including the L-süfixixes. 


\section{The expression of the future}

\subsection{The development of the bad-/b-future in NENA}

The patterns described above are shared across most NENA dialects, but the verbal systems of the dialects commonly differ in other respects, especially in the actual forms of inflections and prefixes. One difference is in the expression of future time reference. As noted, most dialects have a future tense formed by adding the prefix $b \partial d$ - or $b$ - to the present-future base. ${ }^{5}$

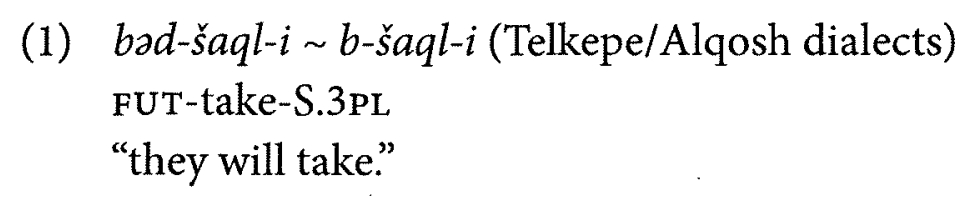

This prefix probably derives from some form of the verb by "to want", which has undergone fossilization (in the 3ms.) and erosion (Maclean 1895: 122): ${ }^{6}$
(2) bad-šāqal < ${ }^{*} k-a b a / b \vec{a} e \quad$ (or $b e$ )
FUT-take.3Ms < IND.PRS-want.3Ms/want.3Ms (or want.PASs.PTCP.3MS)
d-šā $q \partial l$
that-take.3Ms
"he will take." < "he wants to take." or "it is desired that he take."

Evidence for this lies in the variants found in Jewish Azerbaijani dialects, where one variant, $g b e$, is still identical to the original verb in its $3 \mathrm{~ms}$. form $g$-be [IND.PRSwant.3Ms] "he wants" (Garbell 1965:67-68, Khan 2008b:76):

(3) gbe amr-a $\sim b$-amr-a (Southern dialect: be-amra) FUT(-)say-S.3Fs

"she is going to say."

Even more convincing evidence of the particle's origin comes from the dialect of Tal, for which the inflected verb was attested as a future marker in the 19th century (Stoddard 1855: 109):

5. Some Jewish dialects, such as the Sulemaniyya-Halabja dialect, lack a distinct future tense, and use the same form as for the indicative general present (Khan 2004: 102, 285).

6. The form from which the prefix is derived may vary from dialect to dialect, as the prefix was not necessarily inherited from Proto-NENA. It may have developed in certain dialects then spread to others, using the variant of the verb peculiar to each dialect. 


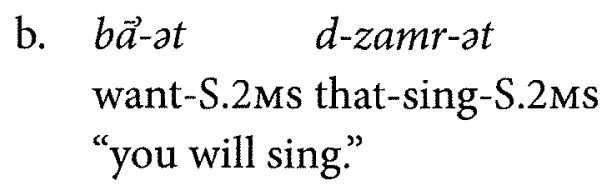

The development of future markers from a verb of volition is of course very common: cf. the English future auxiliary "will" (Bybee \& Pagliuca 1987:112-114).

\subsection{The $z i(l)$ - form in the Mosul Plain dialects}

The $b$-/bad-future tense is common to most dialects. But in some of the Mosul Plain dialects there is another verbal construction expressing the future, not normally found in the dialects further north. This is based on the stem $z i l-\sim z i$ - (henceforth $z i(l)$-), which is inflected with either S- or L-suffixes (cf. \$6). It is a unique form of the verb ' $z l$ "to go". $Z i(l)$ - has two functions: (1) as an independent verb expressing an immediate future and (2) as an auxiliary or uninflected particle expressing future time reference, in conjunction with another verb formed on the unprefixed present-future base. The following examples are from the Telkepe dialect:

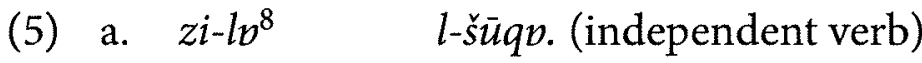

go.IMM-L.3Fs to-market

"She's just going to the market.", "She's off to the market." (immediate future)

b. zi-lv napl-v. (auxiliary verb)

PRSP-L.3Fs fall-S.3Fs

"She's going to fall."

c. zi-napl-p. (particle)

PRSP-fall-S.3Fs

"She's going to fall."

7. It is worth noting that the same verb in Syriac could be used in a construction (involving the Syriac Active Participle) said to express "to be about to" (i.e. the immediate future): 'ena 'äzel-(')nā la-mmät [I going.ACT.PTCP.Ms-I to-die.INF] "I am going to die" (Payne Smith 1902:9). Another construction with this verb was said to express "intention"; the example following is actually of going with intention:'äzel-(')nä'eșü nüne [going.ACT.PTCP.MS-I I.hunt.suBJUNCTIVE fish] "I go a fishing" (= modern English "I'm going fishing", Payne Smith 1902:9). There is no continuity, however, between these constructions and the $z i(l)$ - future in Neo-Aramaic, which is derived from a different part of the verb (the old Passive Participle) and appears to be a relatively recent development.

8. The $/ v /$ vowel in the Telkepe dialect, found only in final unstressed open syllables, corresponds etymologically to $/ a /$ in most other dialects. 
It is worth investigating the finer details of the functions of $z i(l)$-, as it exists alongside other future tenses: the $b$-future and also the active participle ${ }^{9}$ with copula: ${ }^{10}$

(6) a. b-napl-b.

FUT-fall-S.3Fs

"She will fall."

b. ke-lo maxxu?-'aAāya-la 'adyu. (active participle + where-is Mike coming.ACT.PTCP.Ms-he.is today copula) "Where is Mike?" - "He's coming today."

This paper will first cover synchronic aspects of the $z i(l)$ - form in the Mosul Plain dialects: (1) its functions and how it divides the semantic space with other verbal forms, and (2) its various forms in the different dialects. Then, on this basis, it will examine the historical development of $z i(l)$ - and what it reveals about the grammaticalization of futures.

\section{Geographical distribution}

$Z i(l)$ - is attested in the Neo-Aramaic dialects of the Mosul Plain, which are spoken by Christian communities. The Mosul Plain dialects are those spoken in the villages lying north of the city of Mosul, up to the edge of the mountains (from south to north: Telkepe, Bațnaya, Baqopa, Tisqopa, Alqosh) and lying southeast of Mosul (Barțille, Karimlesh, Qaraqosh). The geographical division between the two sides of Mosul is reflected in many aspects of the language, although all these dialects are mutually comprehensible.

Of the Mosul Plain dialects, $z i(l)$ - is attested in all the northern dialects (Telkepe - Alqosh) and one southeastern dialect (Karimlesh, Borghero 2008: 845). It is not attested in Bartille (Kristine Mole p.c.) or Qaraqosh (Khan 2002). It is likely therefore that the construction developed first in the northern villages, then spread to Karimlesh. It is worth noting that of the south-eastern villages, Karimlesh is the only one whose inhabitants belong to the Chaldean Catholic church like the northern villages. It may be that Karimlesh's greater community links to the northern villages was a factor behind its adoption of $z i(l)$-. The following map shows the distribution of $z i(l)$ - among the NENA dialects in Iraq. Only the Mosul Plain dialects are named. Dialects which have $z i(l)$ - are coloured black.

9. The 'active participle' of the modern dialects is not to be confused with the active participle of earlier Aramaic, which became the modern present-future base.

10. Note that the indicative general present form in these dialects (prefixed by $k$-) cannot express future time reference (except when negated, when it also serves as the negative equivalent of the $b$-future). 


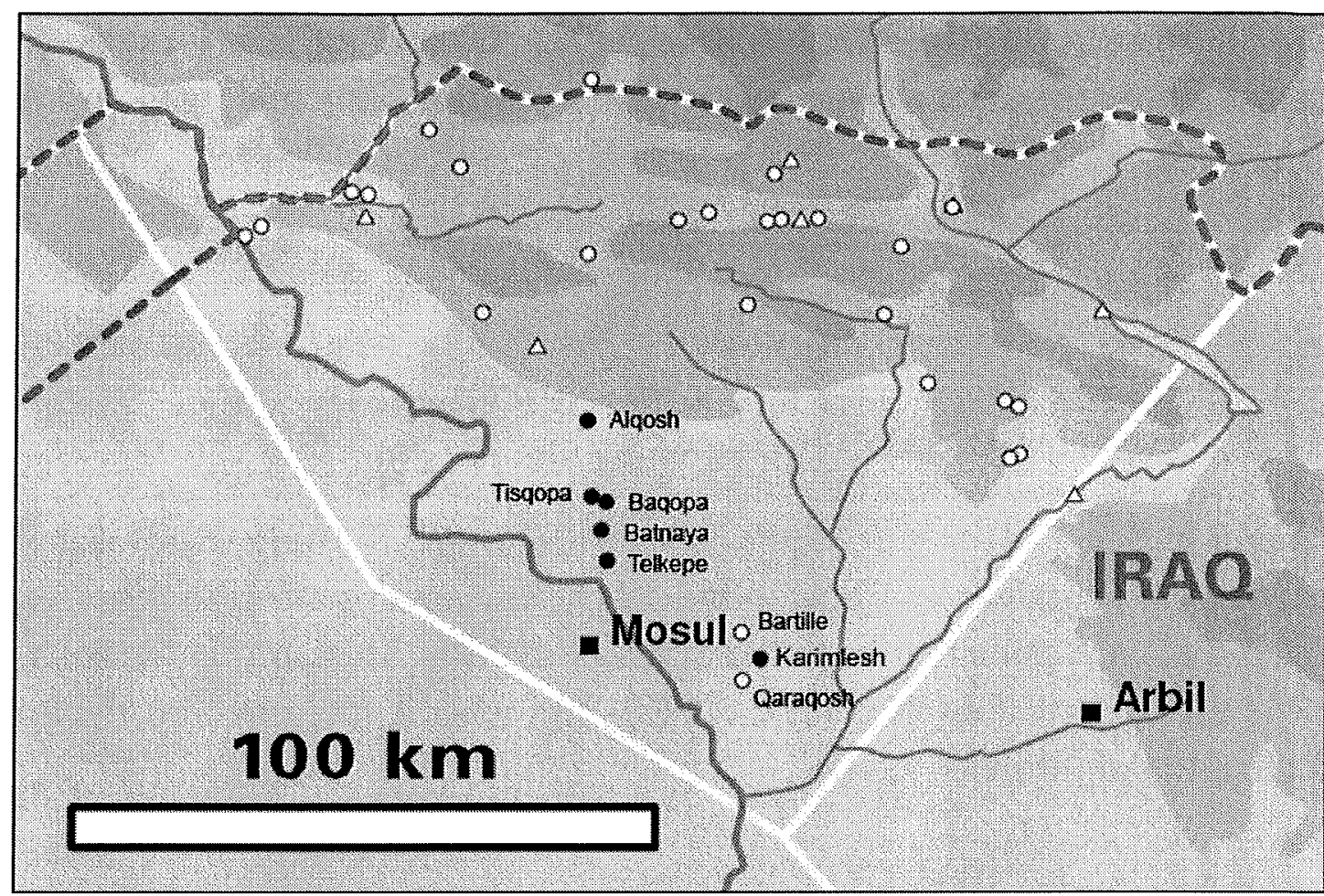

Map of distribution of $z i(l)$ - among the NENA dialects of Northern Iraq
Christian dialects
Dialect with $z i(l)$ -
$\triangle$ Jewish dialects
Dialect without $z i(l)$

Map template courtesy of the North Eastern Neo-Aramaic Project at the University of Cambridge.

\section{Functions of $z i(l)$ -}

The functions of $z i(l)$ - will be examined in greatest detail for the Telkepe dialect, for which the most data has been collected. Some significant differences in its usage in other dialects will be presented in $\$ 5.2$.

\subsection{Functions in the Telkepe dialect}

\subsubsection{As an independent verb}

As an independent verb, $z i(l)$ - is used to express the immediate future of the verb ' $z l$ "to go", in English usually translated with "to be about to go" or "to be going":
a. $z i-l a$
l-šūqu.

go.IMM-L.3Ms to-market

"He's just going to the market." (immediate future)

b. 'āyat zil-at 'ammad-bāb-ux,

you.Ms go.IMM-S.2Ms with-father-your.Ms

"You are going with your father,

'u 'àyat zil-at 'ammad-yamm-ax.

and you.Fs go.IMM-S.2Fs with-mother-your.Fs

and you are going with your mother." 
Note that this construction is not available for other verb lexemes. A parallel to this kind of lexical restriction is found in the Qaraqosh (Khan 2002:349) and Karimlesh (Borghero 2008: 83-84) dialects in the active participle + copula construction, which, unlike in Telkepe, is restricted to two verbs: "go" and "come". 11

This construction can be negated:

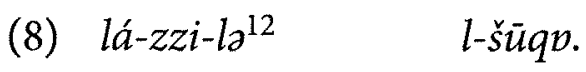

NEG-go.IMM-L.3Ms to-market

"He's not about to go to the market."

\subsubsection{As an auxiliary or uninflected particle}

As an auxiliary verb or uninflected particle, followed by the present-future base, $z i(l)$ - expresses future time reference of the main verb:

(9)
a. zi-lo pāalax. or $z i-p \bar{a} \theta a x$.
PRSP-L.3Ms open.3Ms
PRSP-open.3Ms
"It's going to open/It's about to open."
b. $z i-l v \quad z \bar{a}-l v^{13} \quad l-s \bar{u} q u . \quad$ or $z i-z \bar{a}-l v \quad l-s ̌ \bar{u} q v$.
PRSP-L.3Fs go-L.3Fs to-market PRSP-go-L.3Fs to-market
"She's going to go to the market."

The $b$-future can normally be translated by the English auxiliary will and the $z i(l)$ future by English going to, suggesting a close similarity in their respective functions. ${ }^{14}$ The $b$-future expresses a future which is less a matter of fact and more a matter of opinion - more subjective. It is also used when the future event is contingent on the fulfilment of a condition. $Z i(l)$ - usually expresses a future for which there is already an intention or there is evidence of what is going to happen.

11. Another case of a lexically restricted "tense" is the Maltese active participle, which is used to express continuous aspect for a set of verbs, composed mainly of verbs of motion and verbs of (inception into) a state, such as "sleep", "stand" and "get dressed" (Borg \& Azzopardi-Alexander 1996: 230 and Ebert 2002:767-771, who disputes the progressive function). A similar, though not necessarily identical, function for other verb lexemes is performed by a different construction (qed + Imperfect). In Telkepe, by comparison, the function of the immediate future is lexically restricted: it cannot be explicitly expressed for verbs other than ' $z l$ I. In the dialect of Alqosh, however, there is another form ( $d i^{-}, \mathrm{cf}$. \$5.2) which can serve this function for any verb.

12. The doubling of the initial $/ z /$ of $z i(l)$ here is a phonological feature that often occurs after the negator la-.

13. $z \hat{a}-l v$ : note that the present-future base of $z l$ itself has an irregular form $z \hat{a}$ - which takes Lsuffixes, in contrast to all other verb lexemes, which take $S$-suffixes with the present-future base.

14. See Binnick $(1971,1972)$ and Haegeman (1989) for comparisons of the functions of will and going to in English. 
A speaker can use the $b$-future to express his opinion or to ask another's. For instance, take the situation that some people were waiting for a shop to open: if there was evidence that it was about to open - the owner has been spotted arriving, or someone checks their watch and sees that it's the time it's supposed to open - then one could say:

(10) zil-a pāAlax. "It's going to open."

But if someone wondered whether it was going to open, another might reassure him:

(11) $b-p \bar{a} \theta \partial x$. "It will open."

Likewise someone might reassure the relative of a sick person with the $b$-future:

$$
\begin{aligned}
& b \text {-pāyəš țāwn. } \\
& \text { FUT-become.3Ms good.Ms } \\
& \text { "He will get well." }
\end{aligned}
$$

This tense can also be used in questions when eliciting an opinion, e.g. one might ask:
(13) 'iman b-pāexa?
when FUT-open.3Ms
"When will it open?"

It can also be used in volunteering or promising to do something, expressing intention or willingness:

(14) 'ānv bd-oð-ən-nว. ${ }^{15}$

I FUT-do-S.1MS-L.3MS

"I'LL do it!"

The $b$-future is also common in the apodosis of a conditional sentence, when the condition is possible. ${ }^{16}$

(15) 'on bxe-lux, b-qațl-an-nux.

if cried-2Ms FuT-kill-S.1Ms-L.2Ms

"If you cry I will kill you."

15. L-suffixes assimilate to various preceding consonants, including $/ n /$.

16. Another distinction between the $b$-future and $z i(l)$-is that $z i(l)$ - (in Telkepe at least) can be negated like any other verb, with the verbal negator particle la-, e.g. lá-zzi-la mbäšal [NEG-PRSPL.3MS cook.3Ms] "he is not going to cook". The $b$-future, on the other hand, cannot combine with the verbal negator itself. Instead, the negated indicative general present form (prefixed with $k$-) covers the future function as well as its own functions, e.g. la-k-šăqal [NEG-IND.PRStake.3ms] "he does not take, he will not take". 
As stated above, $z i(l)$ - is used when there is evidence that an action will take place. Another example of this is when gathering clouds lead one to say:

zi-la 'à̈a matro.

PRSP-L.3MS come.3Ms rain

"It's going to rain." (lit. "Rain is going to come.")

$\mathrm{Zi}(\mathrm{l})$ - is also used when plans have been made prior to the action, or there is already an intention to undertake the action:
a. tre $x \bar{u} r-i, \quad z i-z \bar{a}-l a \quad$ mašalx-i bank
two friends-my PRSP-go-L.3PL rob-S.3PL bank
"Two of my friends, they are going to go and rob a bank."
b. 'ânv lá-zi-axl-an wal $d-\bar{a} \theta a \quad l-b e \theta v$.
I NEG-PRSP-eat-S.1Fs until that-come.3ms to-house
"I am not going to eat until he comes home."

On this basis $z i(l)$ - is better termed a 'prospective', like English going to. This is a category which is used, in Comrie's (1976:64) words, "where a state is related to some subsequent situation". Prospectives are used when something is already present which will bring about the future situation or event. This might be a person's present intention ("they are going to go and rob a bank"), or it might be the clouds gathering that draw forth the observation, "It's going to rain." Prospectives are related to perfects, which relate a state to a preceding situation. They can both be considered types of 'perspectival aspect' (Dik 1997:238-240), as they view one time from the perspective of another. It is debatable whether these perspectival categories should actually be grouped under 'aspect' along with imperfective and perfective, categories which deal with the internal temporal constitution of a situation (Comrie 1976:52) or should form their own category. And they combine features of both aspect and tense: the former through describing a state and the latter through relating it to a past or future situation.

There is a past tense equivalent of the $z i(l)$-construction:
(18) $z i-l a$
'ā $\theta e-w v$.
lá-walleba.
PRSP-L.3Ms come.3MS-PST NEG-he.was.able
"He was going to come but he wasn't able to."

This usually has the implicature that the event did not take place, as otherwise the speaker would have simply said $\theta e l a$ "he came". The particle may also be used in this function $(z i \overline{-} \bar{a} \theta e-w b)$. It is worth noting that the past time reference is only marked on the main verb, not on the auxiliary as in English was going to. 
Often $z i(l)$ - is used for an event which is expected to occur in the immediate future, and can be translated as "about to". This is because a current situation is more often relevant to imminent events, as in the following example:
zi-lo näpal
PRSP-L.3Ms fall.3Ms

"He is going to fall/He is about to fall." (said of a child standing on an edge.)

$Z i(l)$ - can however be used for more distant events:
(20) zi-la
$z \bar{a}-l a \quad b a \theta a r$ tatté-šanna.
PRSP-L.3MS go-L.3MS after two.F-years
"He's going to go after two years."

As imminence is not expressed in all contexts, it is only an implicature and not part of the inherent meaning of the form. This contrasts with the meaning of $z i(l)$ as an independent verb (\$5.1.1). Note that Comrie (1976:52) also includes expressions of imminent or immediate future, such as English be about to as a type of prospective aspect. This would suggest that $z i(l)$ - as an independent verb also expresses prospective aspect, but with the additional meaning of imminence. For the lexeme' $z l$ the two can be contrasted:
a. $z i l-a n$
l-bagdad. (prospective, immediate future)
go.IMM-S.1 Ms to-Baghdad
"I'm about to go to Baghdad."
b. zil-an zä-li l-bağdad. (general prospective)
PRSP-S.1Ms go-L.1s to-Baghdad
"I'm going to go to Baghdad." (not necessarily imminently)

$\mathrm{Zi}(l)$ - is also distinguished from another verb form with future time reference. This is an analytical form, the active participle ${ }^{17}+$ copula. This seems to be used more for a scheduled event, one that has been agreed upon, just as the English present continuous is often used:
a. ke-lo maxxu?-'äāya-la 'adyu.
where-is Mike coming.ACT.PTCP.Ms-he.is today
"Where is Mike?" - "He's coming today."
b. (in English) "Is so-and-so going to the conference?" -
'e, 'azāla-la.
yes going.ACT.PTCP.MS-he.is
"Yes, he's going."

\footnotetext{
17. The "active participle" of NENA usually has the templatic form $\mathrm{CaCaCa}$ (f. $\mathrm{CaCaCta}$ ). Active participles also function as nouns referring to persons or things that carry out the activity of the verb, e.g. zamiâra "singer" (from zmr "to sing").
} 


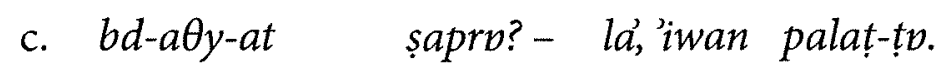

FUT-come-S.2Fs tomorrow no I.F.am going.out.ACT.PTCP-FS

"Will you come tomorrow?" - "No, I'm going out."

Unlike in English, this construction does not also serve for the present continuous; other constructions cover this aspect. ${ }^{18}$

\subsection{Functions in other dialects}

In other dialects too, $z i(l)$ - functions as both independent verb and auxiliary, and co-exists with the $b$-future. Its usage in the other dialects is similar to the usage in Telkepe: as an independent verb it expresses the immediate future, as an auxiliary it expresses prospective aspect. In Alqosh, however, there is a difference in distribution. As an independent verb expressing immediate future, $z i(l)$ - in Alqosh is only available in the 1st person:
a. zil-ən/zi-n $l$-šūqa.
go.IMM-S.1 Ms to-market
"I'm just off to the market."
b. ${ }^{\star} \mathrm{zi}-\mathrm{la}$
$l-s \bar{u} q a$.
go.IMM-L.3Fs to-market
"She's just off to the market."

Note that in addition Alqosh has a specialized immediate future, using the present-future base with the prefix $d i-{ }^{19}$ a construction which exists in addition to the forms we have described and is available for any person and any verb lexeme, not just' $z l$. So, although the independent $z i l$-paradigm is defective, the same function (or a very similar one) can still be expressed through other means:

$$
\begin{aligned}
& \text { dí-zā-la } \quad l \text {-bağdad. = Telkepe } z i l \text { l-bagdad } \\
& \text { IMM-go-L.3ms to-Baghdad } \\
& \text { "He's about to go to Baghdad." }
\end{aligned}
$$

Another difference to Telkepe is that in Alqosh $z i(l)$ - cannot be negated, either as a lexical verb or as an auxiliary:

18. These are: for dynamic meaning, the copula plus infinitive (preceded by $b$ - "in"), e.g. 'ila $b$-ixălv [he.is in-eat.INF] "he is eating", and, for stative meaning, the copula plus stative participle, e.g. 'ila'itiwo [he.is sit.stat.PTCP.Ms] "he is sitting".

19. This future was also attested with a speaker from Tisqopa, albeit one who was not a reliable representative of the dialect; she did not grow up there and mixed her speech with features of dialects from outside the Mosul Plain. 


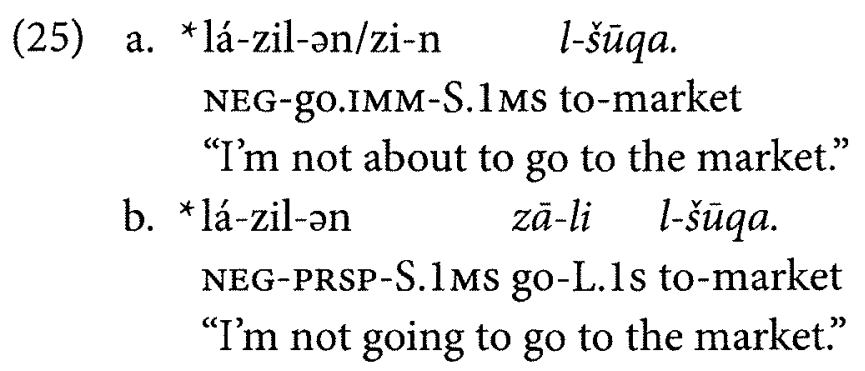

Although the Alqoshi speaker accepted the use of $z i(l)$ - as an auxiliary with the third person, and $z i l$ - as a particle with all persons, he felt that the use of the prospective with 2nd or 3rd persons in Alqosh was as a result of recent influence from other dialects, ${ }^{20}$ and that with non-1st person subjects the more original Alqoshi practice was to use the $b$ - or $d i$ - futures.

In Alqosh, in contrast to Telkepe, the past prospective construction is not allowed:

$$
\begin{aligned}
& (26){ }^{*} \text { zil-ən 'ä } \theta \text {-ən-wa } \\
& \text { PRSP-1Ms come-S.1MS-PST } \\
& \text { "I was going to come." }
\end{aligned}
$$

There are some other distinctions in usage in Alqosh and other dialects that will be discussed as appropriate in the historical section (\$7).

\section{The morphology of $z i(l)-$}

6.1 Forms in the Telkepe dialect

Table 1 shows the paradigm of $z i(l)$ - in the dialect of Telkepe:

Table 1. Inflection of $z i(l)$ - in Telkepe

\begin{tabular}{lll}
\hline 3rd & ms. & zila \\
& fs. & ziln \\
& pl. & zila \\
2nd & ms. & zilat \\
& fs. & zilat \\
& pl. & zilūtu \\
1st & ms. & zilan \\
& fs. & zilan \\
& pl. & zilux \\
\hline
\end{tabular}

20. He săid he would use it, but his mother probably would not. 
The verb is constructed from the past base (CCaC-/CCiC-) of the verb ' $z$ l "to go" $\left(z i l-<{ }^{*} z i l-\right)$ but with the S-suffixes which are usually found with present-future base. In the third person $\mathrm{m}$. and pl, however, the suffixes do not follow the rule, as a comparison with the present-future base inflection shows:

Table 2. Inflection of $z i(l)$ - compared to inflection of present-future base (S-suffixes)

\begin{tabular}{|c|c|c|c|}
\hline & & šaql-S & $z i l-$ \\
\hline \multirow[t]{3}{*}{$3 \mathrm{rd}$} & ms. & šāqal-Ø & $2 i l-2$ \\
\hline & fs. & šaql-u & $z i l-p$ \\
\hline & pl. & šaql-i & $z i l-a$ \\
\hline \multirow[t]{3}{*}{$2 n d$} & ms. & šaql-at & $z i l-a t$ \\
\hline & fs. & šaql-at & $z i l-a t$ \\
\hline & pl. & śaql-ütu & zil-ütu \\
\hline \multirow[t]{3}{*}{1 st } & ms. & saql-an & $z i l-a n$ \\
\hline & fs. & saql-an & $z i l-a n$ \\
\hline & pl. & šaql-ux & $z i l-u x$ \\
\hline
\end{tabular}

The third person forms could in fact be analysed not as $z i l-+$ S-suffix, but as $z i-+$ L-suffix, as Table 3 shows:

Table 3. Inflection of 3 rd person $z i(l)$ - compared to inflection of past base (L-suffixes)

\begin{tabular}{llll}
\hline & & $\check{s} q a l-\mathrm{L}$ & $z i-\mathrm{L}$ \\
\hline 3rd & ms. & $\check{s} q a l-l a$ & $z i-l a$ \\
& fs. & $\check{s} q a l-l v$ & $z i-l v$ \\
& pl. & $\check{s} q a l-l a$ & $z i-l a$ \\
\hline
\end{tabular}

The significance of this will become apparent when we view the forms in other dialects.

\subsection{Forms in other dialects}

Table 4 shows the paradigms found in all the dialects where $z i(l)$ - is attested, arranged from North to South. ${ }^{21}$ Lighter shaded forms are on the pattern $z i l-S$, while darker shaded forms are $z i$-L. Forms in brackets were felt by a speaker to be recent appearances in the dialect through influence from other dialects.

21. Note that the data is taken from only one or two informants per dialect, so idiolectal variation may not be fully represented. 
Table 4. Inflection of $z i(l)$ - in all dialects

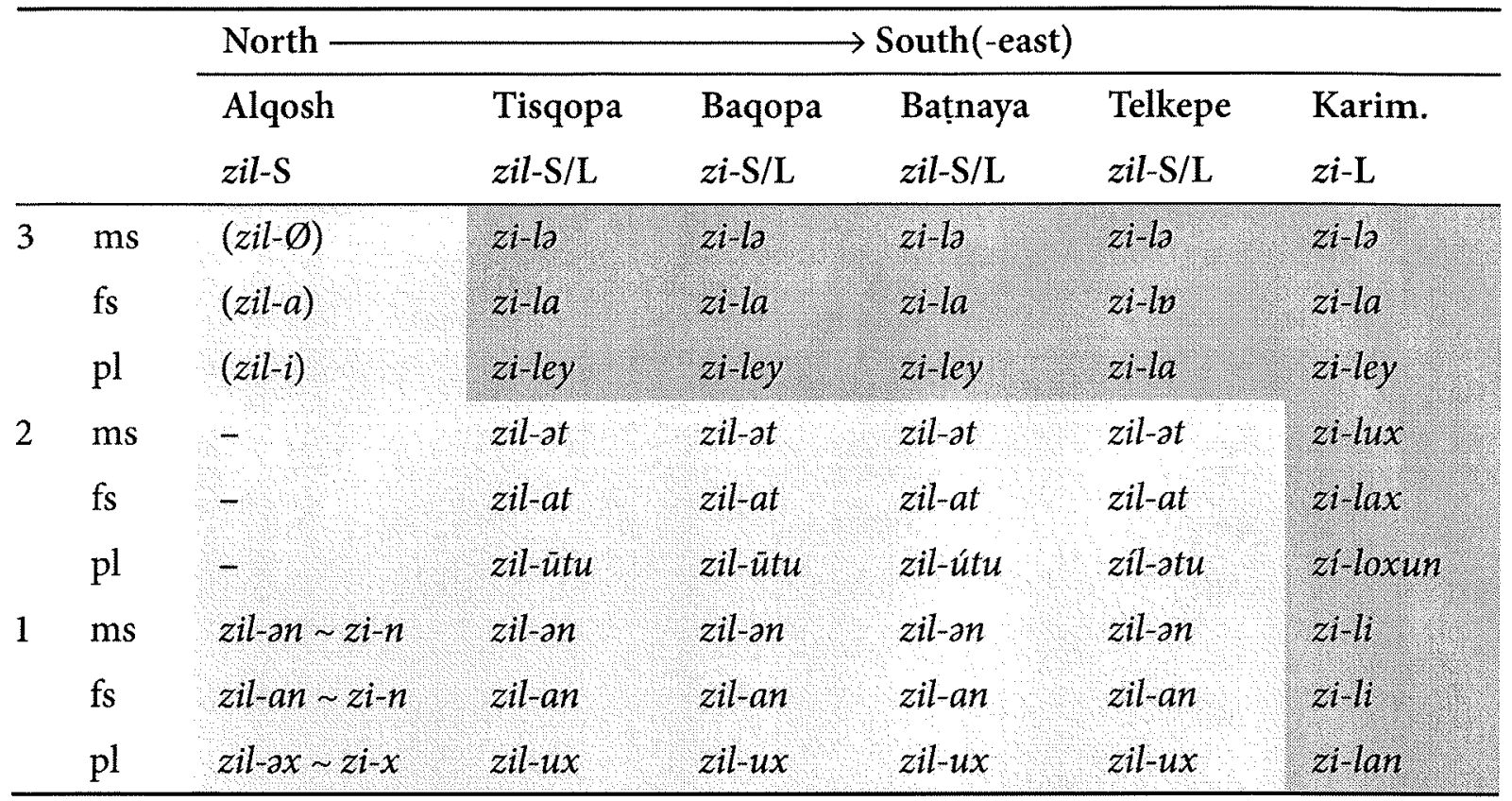

In Alqosh, at the northern end of this zone, only the 1st and 3rd person forms of $z i(l)$ - are used. ${ }^{22}$ These conform to the $z i l-+S$-suffixes pattern. In the dialect of Karimlesh, at the south-eastern end, the paradigm can only be analysed as $z i-+$ L-suffix, and it is consistent in this. The dialects of Tisqopa, Baqopa, Batnaya and Telkepe, in the middle, all have mixed paradigms, where the 1st and 2nd persons are analysed as $z i l-+\mathrm{S}$-suffixes and the 3 rd person as $z i-+\mathrm{L}$-suffix.

In $\$ 8$ it will be shown that this synchronic variation shows different stages of the morphological reanalysis of the paradigm of $z i l-\mathrm{S}$ as $z i-\mathrm{L}$, with ambiguous $3 \mathrm{rd}$ person forms acting as a pivot. Alqosh still retains the original $z$ il-S inflection; the dialects in the middle show an intermediate stage where $3 \mathrm{rd}$ person forms have been reanalysed as $z i$-L; while Karimlesh has reached the final stage of the process, where all persons are inflected as $z i$-L.

A free variant to $z i(l)$ - in its role as auxiliary is the fossilized particle, $z i l$ - or $z i-$, which binds to the following verb as a prefix. The form in Alqosh is $z i l$ - and in Tisqopa it is $z i$-. In Telkepe it is mostly $z i-$, but one informant alternated this with $z i l$ - and another reported hearing this usage among Telkepe speakers. The youngest Telkepe informant (in his 20s) used only a devoiced $s i$-:

$$
\begin{aligned}
& \text { a. } \quad z i l \text {-amr-an (Alqosh) } \\
& \text { PRSP-say-S.1Fs } \\
& \text { "I'm going to say." }
\end{aligned}
$$

22. For the prospective in Alqosh the particle $z i l$ - may be used with 2 nd person verbs, as the auxiliary is not available, e.g. zil'axlat? "Are you going to eat?" (not *zilat'axlat). Again, however, the informant felt this usage to be a borrowing from other dialects. 


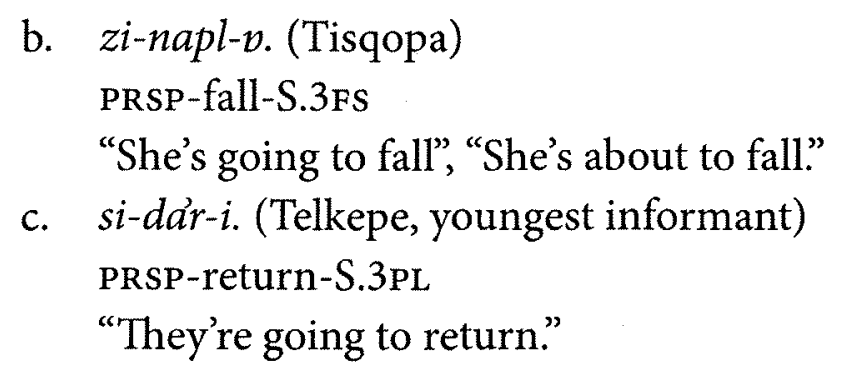

The auxiliary verb is used rather than a fossilized particle in Baqopa, Bațaya or Karimlesh.

\section{Historical Development of $z i(l)$ - functions}

7.1 The age of the $z i(l)$ - constructions

$Z i(l)$-, in both its functions of future time reference, is found only in a few NENA dialects, while the $b$-future is found perhaps in the majority of NENA dialects. This would suggest that future $z i(l)$ - is a relatively late-developing construction. $Z i(l)$ - in its modern functions is unattested in the early literary texts of the Mosul Plain area dating to the 17th century (Alessandro Mengozzi p.c.), suggesting either that these functions did not exist, or that they were too new and colloquial-sounding to be used in literature. The inflected form is included in an early 20th century grammar by the French missionary and scholar Jacques Rhétoré (1912:156), as an independent verb (with a somewhat ambiguous translation, cf. \$7.2), but with no mention of its use as an auxiliary. It is entirely absent from the slightly earlier grammatical sketch of the same dialect group by Eduard Sachau (1895). It appears then that the modern functions of $z i(l)$ - have developed relatively recently.

The relative age of the $z i(l)$ - and $b$-futures is also reflected in the forms themselves. The $b$-future in most NENA dialects, including those of the Mosul Plain, usually consists of a monoconsonantal prefix, with little evidence remaining of the inflected verb it is derived from. The $z i(l)$-future, on the other hand, may still be formed from a fully inflected auxiliary verb, and the $z i(l)$-fossilized particle has only been adopted in some of the dialects. Therefore it is formally at an earlier stage of grammaticalization.

7.2 The origin of $z i(l)$ - in a form with perfect aspect

$Z i(l)$ - is a form of the verb ' $z l$ "to go". In both its functions, as an independent verb and as an auxiliary or particle, it has meanings connected to future time reference. In the world's languages it is common for a verb 'to go' to develop into a future 
marker. But what is the exact form that $z i(l)$ - derives from, and how exactly did it develop its modern functions?

Judging by its forms, especially in Alqosh, $z i(l)$-is a past base $\left(<^{\prime} z \bar{l} l-\right)$ inflected with S-suffixes (on the intrusion of L-suffixes cf. \$8.1.1). The past base derives from an earlier Aramaic 'passive participle' in the 'absolute state', on the pattern $C C i \mathrm{C}$. The absolute state of Aramaic was the form of nominals used for predication. The temporal function expressed by the passive participle in the absolute state was the present perfect. The participle agreed with the subject, which would be an NP or enclitic pronoun:

(28) kūbe $\bar{e} \quad$ qì $r$ in (Syriac, Nöldeke 1904: \$278)

thorns uprooted-MPL

"the thorns have been uprooted."

For intransitive verbs the (active) present perfect would usually be expressed instead by one of two verbal adjectives, $\mathrm{CCeC}$ (mpl. CaCC-in) or $\mathrm{CaCCi} C$ :

(29) damk-in-nan (Syriac, Payne-Smith 1902:94)

having.slept-MPL-we

"we have fallen asleep/we are asleep."

This appears to cause a problem, as ' $z l$ "to go" is intransitive and we might expect, instead of a reflex of ' $z \bar{l} l$, one of these specialized intransitive forms (i.e. 'zel or 'azzill). The pattern $\mathrm{CC}_{\bar{i}} \mathrm{C}$ is however attested with intransitive verbs in Syriac. ${ }^{23}$

In some NENA dialects a reflex of the $C C^{i} C$ construction is still found. We may therefore expect that the construction was also present in the ancestor of the NENA dialects. In the modern dialects it is mostly used to express the passive (with past time reference). Note that in NENA the old enclitic pronouns have merged with gender/plural suffixes to form the S-suffixes, so the construction is now analyzable as the past base + S-suffixes, or PAST-S:

(30) $p \theta i x-i$ (Jewish Amadiya, Hoberman 1989:36) opened-S.3PL

"they were opened."

(31) la drē-na go mahzar dēhun (Jewish Nerwa text, Sabar 1984:89) ${ }^{24}$ not put-S.1s in assembly of:them

"I was not put in their assembly."

23. Cf. dnīh "has risen" (Duval 1881:225).

24. Following the transcription of Goldenberg (1992:120). 
PAST-S with a past-passive usage was also reported for the Mosul Plain dialects by Rhétoré (1912:106) 100 years ago. It is still attested in Telkepe, though only with some older speakers:

(32) 'án-šulāna wið-i.

these-jobs done-S.3PL

"These jobs have been done."

In some Jewish dialects, such as Sulemaniyya, PAST-S is used for intransitives, complementing the transitive past base $+\mathrm{L}$-suffix paradigm (PAST-L): ${ }^{25}$

(33) (Sulemaniyya, Khan 2004:86-7)

a. $p l a x-l i^{26}$

opened-L.1s

"I opened."

b. priq-na (-na is equivalent to Telkepe -an)

finished-S.1Ms

"I (m.) finished."

This is a survival of the original NENA distribution. In most NENA dialects the PAST-L paradigm has since spread to intransitives. This has not necessarily involved the disappearance of intransitive PAST-S. In some dialects it survived with a specialized function, as will be shown below.

The past-base with S-suffixes is not attested with intransitive verbs in the Mosul Plain dialects today, ${ }^{27}$ but there are traces of an intransitive use in early texts (dated to the 17th century) from this area, composed by authors from Alqosh and Telkepe. Examples have been collected by Mengozzi (2002:33), most of which are listed below (transliterated from Syriac script): ${ }^{28}$

25. PAST-L is derived from a passive with agent (marked by the preposition $l$ - "to"): šqal-lo "he took" derives from šqül lëh "it has been taken to/by him", cf. Coghill \& Deutscher (2002).

26. $<{ }^{*} p \theta \partial x-l i$, as ${ }^{\star} \theta>l$ in this dialect. Khan's transcription ( $\left.p l i x x l i\right)$ has been adapted in line with the other dialects.

27. The past base with S-suffixes is found marginally in Alqosh and Telkepe with transitive verbs (with a passive function), but not attested at all in Tisqopa, Baqopa, Batnaya, Karimlesh (own fieldwork), Qaraqosh (Khan: p.c.) or Barțille (Kristine Mole: p.c.).

28. Where they differ, the translations have been taken from the full translations of the texts (Mengozzi 2002:148, 152, 154, 144, 230), i.e. from context, rather than from the quotes given on 33. 


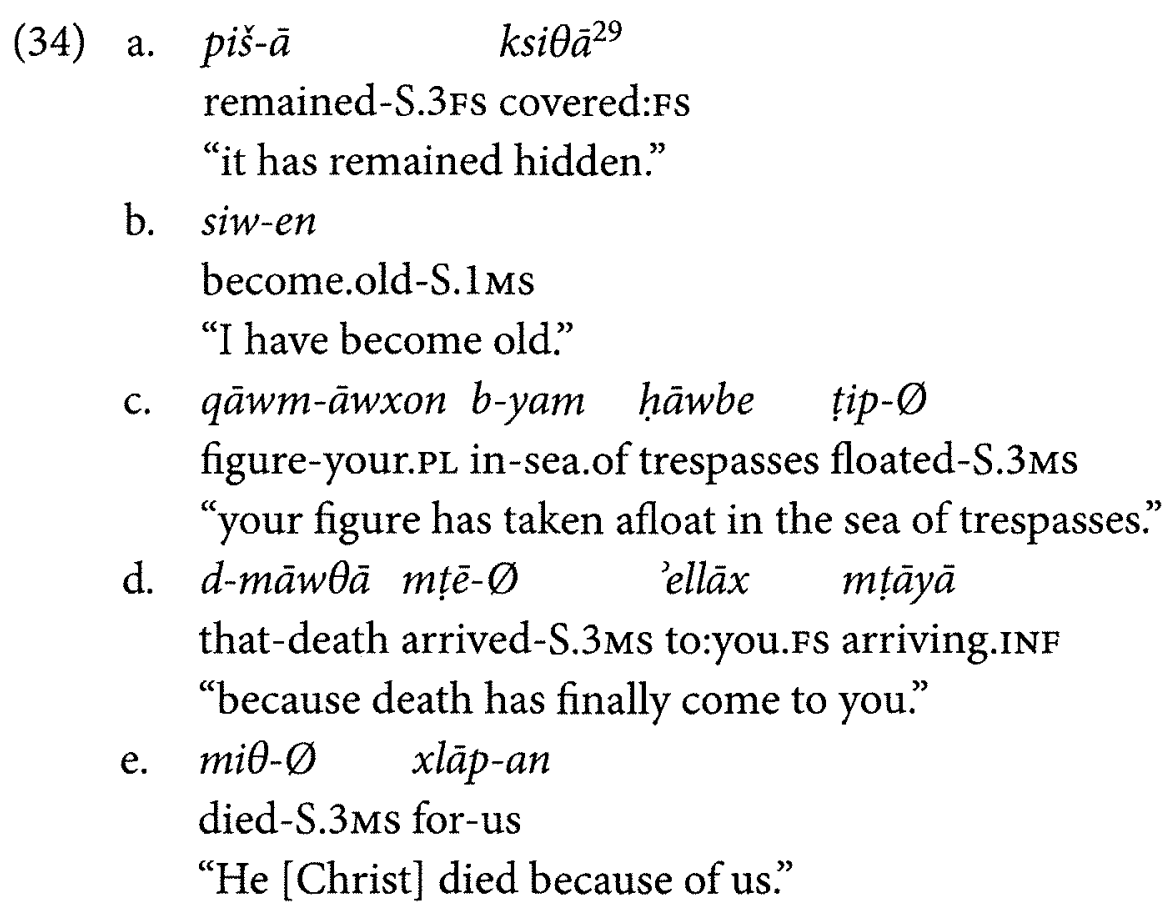

The contexts in which the forms are found strongly suggest present perfect aspect (i.e. a past action with consequences in the present).$^{30}$ Given that PAST-L could also be used with intransitive verbs in these texts, it may be that the function that intransitive PAST-S carved out for itself was to express explicit perfect aspect, ${ }^{31}$ in contrast to PAST-L, which had by now become a general past perfective. This is in fact still the function of PAST-S in a modern NENA dialect, that of Hertevin (Jastrow 1988: 49):
a. qtel-li
killed-L.1s
"I killed."
b. dmeh-li
slept-L.1s
"I slept."
c. dmih-en
slept-S.1s
"I have fallen asleep."

\footnotetext{
29. The $3 \mathrm{~ms}$. form of this verb, piš, is still found (in Alqosh, Telkepe and Baqopa at least), uninflected, as an existential predicator meaning "there is ... remaining".

30. Even the last example, translated with the English past simple, might be understood in this sense, as the death of Jesus could be represented as having continuing consequences in the present.

31. Note this distinction was not available to transitive verbs used actively: the same constructioñ with a trañistive verto woüld hàve a passivive señse.
} 
The same distribution is found in the Jewish Azerbaijani dialect (Garbell 1965:70).

The next evidence we have is from the French scholar Rhétoré (1912:156), who was in the area during the last quarter of the 19th century and the first quarter of the 20th, and wrote a grammar of the Mosul Plain dialects. He makes no reference to PAST-S with intransitive verbs, except for $z i l$-sn itself, which he translates with the French Perfect. ${ }^{32}$

(36) zilan "je (m.) suis allé." (English "I have gone.")

The sample forms he gives, transcribed from the Syriac script, are: $1 \mathrm{~ms}$. zilan, $1 \mathrm{fs}$. zilan, 2ms. zilat, 2ms. zilat, 3ms. zil and 3fs. zila.

Intriguingly Rhétoré said that this form was used in Alqosh for "le present (je vais, etc.)". As French je vais can be used for the immediate future, just as English I'm going, ${ }^{33}$ one wonders whether he had this use in mind. Unfortunately Rhétoré does not give an example in context. Nevertheless this attestation provides a concrete link between the original perfect function (now lost) and a non-past function. One can surmise that a hundred years ago a perfect function coexisted with a newer immediate future sense. Since then, the past time reference has been lost.

To summarize, it appears that in Proto-NENA intransitive verbs could be used in the PAST-S construction, complementing the transitive PAST-L paradigm. When PAST-L spread to intransitives, as happened in much of NENA, intransitive PAST-S became specialised in some dialects as a present perfect, contrasting with PAST-L which had lost the explicit present reference of the perfect and had become a general past perfective. The perfect PAST-S construction survives in some dialects today, and was still used in the dialects of the Mosul Plain in the 17th century. Although intransitive PAST-S is no longer generally found in these dialects, it has survived for one lexeme ( $z l$ "to go"), with new functions.

\subsection{The development of future time reference}

But how did this form come to express future time reference as an independent verb? It is not unknown for a past perfective (or present perfect) form ${ }^{34}$ to be used

32. The French Perfect, in the modern spoken language, is a general past perfective, without any necessary sense of continuing relevance to the present. However, the fact that Rhétore chose this form over the simple past, which he used for the PAST-L form, e.g. zalli “j'allai", suggests that he intended to specify present perfect meaning for zilon.

33. For example, French Je vais au marché "I'm going to the market" can be said just before departure, in the same way as the English phrase.

34. Or perfective form, where no tense distinction is made. 
with an immediate future sense. Cross-linguistically examples can be found, particularly with translocative verbs and in the first person: ${ }^{35}$

(37) ja pošël (Russian) $)^{36}$

I go.PST.PFV.M

"I'm just leaving." (lit. "I left", said when one is about to leave)

(38) a. umad-am (colloquial Persian) ${ }^{37}$

come.PST.PFV-1s

"I'm just coming." (lit. "I came", in reply to knock on the door or

"hurry up!")

b. raft-im

go.PST.PFV-1PL

"We're off., "We're going." (lit. "We went.")

(39) a. maĩ $a b h \bar{\imath} \quad \bar{a} y-\bar{a}$ (Hindi/Urdu) $)^{38}$

I.DIR right.now come.PFV-MS

"I’m coming right now." (lit. "I came right now.")

b. maĩ abhī pahũc-i

I.DIR right.now arrive.PFV-FS

"I'll reach (you) right away." (lit. "I arrived right now.")

(40) I'm gone. (American English, meaning "I'm about to walk out of the door.") 39

A similar usage is also found in NENA dialects, with the past perfective PAST-L. This is attested in contemporary Telkepe dialect and the (non-Mosul Plain) Barwar dialect:
a. (har)'äyi-wan $\theta e$-li. (Telkepe)
(just)-here-I.F.am came-L.1 $1 \mathrm{~s}^{40}$
"I’m (just) coming right away." (lit. "Here I am I have come.")

35. Tavangar \& Amouzadeh (2006:98-99) add idioms from Swedish, Turkish (though oddly transcribed) and Kurdish to this list.

36. Comrie (1985:20) and p.c. from a native speaker.

37. The Persian data is from Moshiri (1988:32-33) and Alireza Khormaei (p.c.). Cf. Tavangar \& Amouzadeh (2006) on this usage as well as other future-oriented uses of the past tense in Persian.

38. Elena Bashir (p.c.). See also McGregor (1972: 170-171). The same type of expression is also found in Punjabi: mãi huNe aaii. "I come right away", lit. "I came right away" (Bhatia 1993:244).

39. Ronald Moe (p.c.). This might be said in answer to the question "I thought you were leaving", with the meaning "I expected you to have left by now".

40. Note that the NENA inflected past base (PAST-L) can be used for recent past, i.e. English "I have corme" as well as "I came". 
b. 'āna zal-li kas-bāb-i. (Barwar, Khan 2008a:616)

I went-L.1s beside-father-my

"I am going just now to my father." (lit. "I have gone to my father.")

The association with verbs of translocation ${ }^{41}$ in the first person may have the following explanation. If a past perfective form can be used with immediate future meaning, there is potential ambiguity between the two meanings. With verbs of translocation, however, when used with reference to oneself, there is normally no ambiguity. In most of human history, conversations could only take place when both speaker and hearer were within hearing range of each other. If someone said "I've gone", but was still in the presence of the hearer, then clearly the immediate future interpretation would be preferred. The case of "come" is similar: if someone said, "I've come", but was still some distance off, again a future interpretation would be preferred. With many other verbs, for example "eat", the evidence would not necessarily be available to rule out the past interpretation. Translocative verbs are not, however, the only verbs that avoid ambiguity. A past time interpretation could also be ruled out for the phrase "I've died". In fact, in colloquial British English, it is possible to say "I'm dead", when one is expecting imminent punishment (not necessarily death). In the Barwar dialect of NENA, mentioned above, the past perfective for immediate future can also be used with this verb:

(42) mit-li m-kapna. (Khan 2008a:616)

died-L.1s from-hunger

"I am dying of hunger."

Used with the third person, however, there would be ambiguity whatever the sense of the verb, unless the person or thing spoken about happened to be in front of the people conversing. In fact, there is an example from Barwar of just such a case:

qid-le be $\theta i ! \quad($ Khan 2008a:616)
burned-L.3ms house:my ...
"My house is burning down!"

With the second person, ambiguity could be avoided, just as for the first person. It is, however, normally unnecessary to predict to someone their immediate departure or arrival, so one would only expect it as a question, or perhaps as a command.

Other factors are at play, however. Regarding the use with translocative verbs, it may be that humans in many cultures have a special need to be able to express immediate departures and arrivals, for instance in order to reassure someone who is waiting. The connection to the first person could be that it is easier for a speaker

41. The examples I have so far found in grammars and through personal communication are almost all for verbs of going, coming or similar functions. 
to make promises about his own actions, over which he has most control. This has been discussed with regard to future tenses in general as follows:

we predict that futures from desire (and other types as well) [italics added] will go through a stage in which the form is used for the statement of intentions, initially in first person and later in other persons. We have documented this process for English, where we found a large proportion of tokens of will in Middle English and Early Modern English used for the statement of first-person intention or functions classifiable as promises or resolutions, often with nuances of willingness (Bybee \& Pagliuca 1987). (Bybee, Perkins \& Pagliuca 1994:255-256)

The question remains of what precisely is achieved by using a past tense in this way and why the normal strategies for the future are not used. Tavangar \& Amouzadeh (2006), focusing on the Persian case, suggest the reason can be found in the assymetry of past and future time reference. Unlike the future, which is uncertain and speculative, the past is closed: "statements about the past are either true or false when uttered" (Tavangar \& Amouzadeh 2006: 107). The past tense is therefore associated with "certainty of occurrence". This "explains why it is prioritized over its non-factive or contrafactive future counterparts when assertiveness about futurity is prominent" (Tavangar \& Amouzadeh 2006:98). The examples given above would certainly seem to come from contexts where the speaker is asserting the certainty of an occurrence, typically in promising or reassuring someone who is waiting for them to leave or arrive. In these contexts the normal future strategies might not be considered strong enough. Note that in the Persian, Russian and Hindi-Urdu cases, at least, the verb cannot be negated without changing the meaning (Tavangar \& Amouzadeh 2006: 110-113, Russian speaker, p.c., Elena Bashir, p.c.). No doubt negation would conflict with the function of assertiveness which is the very reason for the use of a past tense in this case.

It seems therefore that the immediate future use of $z i(l)$ - as an independent verb could have grown out of such a pragmatic usage with ' $z l$ "to go" in the first person:

zil-an "I have gone." > "I'm (just) about to go."

Judging by the cases of other languages, as well as the arguments above, it is probable that $z i(l)$ - originally could not be negated in this function. In fact some dialects (Alqosh, Baṭaya and Karimlesh) still do not allow negation of $z i(l)$ - as an independent verb. 


\subsection{The loss of the present perfect function}

The difference between $z i(l)$ - and the constructions cited above from other languages is that the original function of past time reference is now lost to this form. The immediate future sense is no longer a pragmatic usage, but the sole meaning of the form as an independent verb. This loss of past time reference is associated with the spread of PAST-L to intransitive verbs, as happened in most NENA dialects, as well as the development of new analytical forms expressing the perfect. These developments will now be examined.

When PAST-L spread to intransitives, intransitive PAST-S was not lost all at once. As shown in $\$ 7.2$, it was still found occasionally in 17 th century texts from the Mosul Plain, even though intransitive PAST-L was already well established in this period. The adoption of PAST-L for intransitive verbs did not trigger the immediate and total loss of PAST-S; but rather intransitive PAST-S coexisted with PAST-L, whilst becoming increasingly rare and specialized in its use.

At the time of Rhétoré, 100 years ago, intransitive PAST-S survived for ' $z l$ $(\$ 7.2)$, still with past time reference, but with an additional non-past usage. There is no mention of this form with any other verbs, so it was almost certainly restricted to this one lexeme. Therefore it could no longer be considered a distinct tense category in the verbal system, but rather a unique form for this lexeme. Today, no trace of the past time reference of $z i l-a n$ survives in the Mosul Plain dialects. The functions of past perfective and present perfect in these dialects can be performed by PAST-L and newer analytical verb forms:
a. zal-la. (all Mosul Plain dialects)
went-L.3Ms
"he went", or "he's gone."
b. 'ilo zilv. (Telkepe)
he.is gone.Ms
"he's gone."

The immediate future function of $z i(l)$-, however, was not transferred to these constructions along with the other functions. This function was retained along with the form. The retention of the form was supported by the additional function that had now developed for $z i(l)$-, that of future auxiliary. As the form $z i(l)$ - was still available, perhaps it was not necessary to transfer the immediate future function to $z a l-\mathrm{L}$, and so it was retained. In the dialect that lacks $z i(l)-$, however, $z a l-\mathrm{L}$ is indeed attested in this function (see example 41b).

There appears to be a close parallel to these developments in dialects of Hausa, which not only have a special form for the immediate future of 'to go' (the 'allative') but also use this as an auxiliary for prospective aspect. Abdoulaye (1999) describes 
a path of development almost identical to the Neo-Aramaic one, so we shall examine it in some detail. As in Neo-Aramaic the special paradigm is only available for a verb lexeme meaning "go", namely zâa. Unlike in Neo-Aramaic, this lexeme is apparently only used in this paradigm. A different lexeme, jee, is used for "go" in other TAM categories. As we shall see, however, Abdoulaye argues that these two verbs are historically identical, which would make the Hausa and Neo-Aramaic cases even closer parallels. Used as a lexical verb, zâa expresses more or less the same function as $z i(l)$-. Abdoulaye translates it with "be going" and only remarks that "the tense/aspect semantics of the sentences is close to the continuative aspect". According to Jaggar (2001: 198-199), however, zâa "typically expresses actions which are future with respect to the moment of speaking, corresponding to an English imminent/ingressive 'be going to, be off to, be on the way to, etc.' construction with locative goal complements":
(45)
in $\bar{a} \quad z \hat{a} \quad k a ?-z \hat{a} \quad$ nil zân $\quad k \grave{\bar{a} u w a ̄ a ~(J a g g a r ~ 2001: 199) ~})^{42}$
where ALLAT 2M - ALLAT 1s/ ALLAT:1s market
"Where are you off to?" - "I'm off to the market."

In distribution this construction is closest to the $z i(l)$ - of Telkepe rather than Alqosh, as it is available for all persons and can be negated.

The allative $z \hat{a} a$ has an unusual inflection, taking pronouns after the verb, rather than before as is usual for Hausa verbs. Abdoulaye (1999:4-7) gives an explanation for this involving derivation from a perfective form of jee 'go' which historically took (and still takes in some dialects) 'intransitive copy pronouns' after the verb. The phonetic difference between $z \hat{a} a$ and jee, according to him, is accounted for by a phonetic alternation between alveolars and palato-alveolars, as well as the historical presence of an inchoative marker, $(C)$ àa:

$$
\mathrm{JEE}+(\mathrm{C}) \mathrm{àa} \rightarrow \mathrm{ZÂA}
$$

The person/tense/aspect marker that would normally come before a Hausa verb has at some point been lost, leaving simply $z \hat{a} a+$ PRONOUN.

Abdoulaye (1999:6-7) suggests that the 'continuative' aspect of $z \hat{a} a$ can be accounted for by this inchoative marker, as a perfective of an inchoative verb does not imply that the action is over. Hausa has some other inchoative verbs which behave in this way, taking a perfective for actions which are ongoing. This explanation differs slightly from the one given above for $z i(l)$-: a past tense used to assert an immediate future action. Given Jaggar's definition of $z \hat{a} a$ as expressing a future (rather than an action already in progress), perhaps 'continuative' is not the most precise description of the aspect of $z \hat{a} a$, and Abdoulaye's explanation of 
its meaning therefore might not be sufficient. It might have happened that the immediate future function developed from the 'continuative' aspect. It should, however, be considered whether Hausa $z \hat{a} a$, like $z i(l)$-, might have developed through a pragmatic use of a (past) perfective for immediate future. ${ }^{43}$

Hindi-Urdu provides another case of a future particle derived from a past/ perfective form of a translocative verb (Beg 1988: 191): the future affix $-g(\bar{a})$, which is derived from the past participle of the Sanskrit verb for 'to go'.

\subsection{Extension of immediate future $z i(l)$ - to other persons}

It may be that it was only when the past time reference was lost and with it the possibility of ambiguity, that $z i(l)$ - in the immediate future sense might be used with the third person:

(46) $z i l-a$

go.IMm-S.3FS

"She’s about to go."/* "She’s gone."

Bybee, Perkins \& Pagliuca (1994) outline how a nascent future might be extended to other persons and take on a meaning of prediction:

While our evidence is not always of even quality, we hypothesize that all futures go through a stage of functioning to express the intention, first of the speaker, and later of the agent of the main verb (Bybee \& Pagliuca 1987, Bybee 1988a). The meanings that can feed the future path must be meanings that appropriately function in statements that imply an intention on the part of the speaker. This implication of intention later becomes part of the meaning of the gram. A second inference leads to the meaning of prediction: the attribution of an intention to a third person can, in context, imply a prediction on the part of the speaker. (Bybee, Perkins \& Pagliuca 1994:254)

While $z i(l)$ - as an independent verb is not a true future tense, being restricted to one lexeme, the same principles apply.

In the dialect of Alqosh the extension to other persons has not taken place (\$5.2). It seems it is at an earlier stage in the process, where it can only express the speaker's intention, not intentions of other persons, nor pure predictions. In Telkepe, on the other hand, it has been extended to express predictions about others (2nd or 3rd person), as also happened in Hausa ( $\$ 7.4$ ):

43. Jaggar (p.c.), however, disputes the derivation of $z \hat{a} a$ from jee and hence also the development perfective to immediate future. 

a. zi-lo $\quad l$-šùqu.
go.IMM-L.3Ms to-market
"He's just off to the market."
b. 'àyat zil-at 'ammad-bābux
you.Ms go.IMM-S.2Ms with-father:your.M
"You are going with your father."

\subsection{Negation ${ }^{44}$}

I suggested above that the original pragmatic use of perfect $z i(l)$ - for future did not allow negation. We have no historical record of this stage, but some modern dialects do not allow negation of independent $z i(l)$ - $(\$ 7.3)$. Another result of disconnecting $z i(l)$ - from its original function may be removal of this rule. While immediate future $z i(l)$ - was simply a pragmatic use of a past tense to assert the certainty of a future occurrence, negation might not have been possible. Once $z i(l)$ - became a more neutral expression of immediate future (rather than an assertion of certainty), then negation could be allowed, although it might take time for the change to be enacted. In Telkepe, Tisqopa and Baqopa we do indeed find that immediate future $z i(l)$ - can be negated:

(48)
la-zzil-on
l-šūqu. (Telkepe)
NEG-go.IMM-S.1Ms to-market
"I am not going to the market."

7.7 The development of $z i(l)$ - into a prospective marker

\subsubsection{Translocative verb to future time reference}

We turn now to the function of $z i(l)$ - as a prospective auxiliary with other verbs. A translocative verb turning into a future marker is a common development in languages (e.g. Heine \& Kuteva 2002:161-163). A well-known example is English going to:

(49) I'm going to leave at 5 o'clock.

Reanalysis from lexical to grammatical meaning can be seen to have occurred when the auxiliary is found in contexts where a translocative interpretation is not

44. Note that in these dialects, and many others, simple verb forms are negated with the particle $l a-$, which precedes the verb form, e.g. la- $\theta e-l i$ [NEG-came-I] "I didn't come". Analytical forms involving the present copula ila "he is" (which has a distinct conjugation) use a special negative copula instead: lelo (<*la-ila) "he is not". 
possible. An example is co-occurrence with the verb 'to go', which is possible both in English and Neo-Aramaic: ${ }^{45}$

(50) I'm going to go next week.

(51) $z i-n \quad z \bar{a}-l i$. (Alqosh)

PRSP-S.1s go-1s

"I'm going to go."

Another sign is the extension of the construction from the first person (where intention is easiest to identify) to third person subjects, where intention is less transparent ( $c f . \$ 7.5$ on the independent verb). This extension is well established in Telkepe, Baṭnaya, Baqopa, Tisqopa and Karimlesh, but less so in Alqosh, where the informant felt it to be a usage recently borrowed from other dialects (cf. \$5.2).

A later stage of grammaticalization is extension to an inanimate subject, one that lacks volition, which cannot be going with a purpose. With an inanimate subject the construction must be interpreted instead as a prediction. In all dialects the construction can indeed be used with an inanimate subject. In Alqosh, again, however, the informant perceived this to be as a result of recent influence from other dialects:

(52) zi-lv napl-v 'ilänv. (Baqopa)

PRSP-L.3Fs fall-3Fs tree

"The tree is going to fall."

A relatively close parallel to the development of the zil-auxiliary is the colloquial Levantine Arabic verbal particle rah- which expresses prospective aspect. ${ }^{46}$ This is derived from the active participle râyih "going":47

'addēs rah-tiba hōn? (Rice \& Sa'id 1960:59)
how.much PRSP-you.Ms.stay here
"How long are you (ms.) going to stay here?"

Some speakers still retain the original form and inflection of the participle (Rice \& Sa'id 1960:59), demonstrating clearly the origin of the particle:

45. Marchese (1986:101) uses this test to identify the reanalysis of Kru future auxiliaries from 'go' verbs.

46. Cowell (1964:322-323) calls it 'the particle of anticipation': "The particle of anticipation generally indicates that what the following verb refers to is impending in the future, as a consequence of present intentions or a course of events already under way. It is commonly translatable as 'going to .... Often, however, it carries a sense of imminence or immediacy, best translated as 'about to...."

47. See Rubinin (2005:34-38) fờ à discūssion of rạh and its development. 
(54) a. 'addēš räyh-ìn tibu hōn? (Rice \& Sa'id 1960:59)

how.much going-PL you.PL.stay here

"How long are you (pl.) going to stay here?"

b. wèn räyh-in? (participle used independently, elicited from where going-PL

"Where are you (pl.) going?"

Syrian speaker)

While future tenses are derived from a variety of sources, including desire verbs, translocative verbs, expressions of obligation and temporal adverbs (Bybee, Perkins \& Pagliuca 1994:243ff.), prospective meaning seems to have a particular link to translocation. Dahl (1985:111-112) and Comrie (1976:106) both note the connection. Some other languages they mention which have prospectives derived from "go" (or "come") are French, Afrikaans, Igbo and Fante. Two others are Rama (Craig 1991:475-477) and Hausa (Abdoulaye 1999). The Maltese future, which uses the particle derived from an active participle sejjer "going", also appears to be a prospective, judging by examples of its use (Ebert 2000: 763-764). ${ }^{48}$

The explanation seems to be that be going to starts out as an expression of a present situation leading to a future one: one is in the process of going somewhere in order to do something:

(55) He's going (in order) to meet them.

Hence it is a short step to a prospective, which describes a present situation containing the seeds of a future situation.

However, desire futures also begin as a description of a present state (desire being a state of mind). What then is the difference between them? Looking at prospectives, the two main ways that the present component is represented are: present intention (of bringing about a future situation) and present evidence (for a future situation). In expressions of desire, the first component is present, but the second is unlikely to be, given that desire, unlike motion, is not necessarily detectable to another. Therefore we would expect a future from a verb 'to go' to express a future situation the origin of which is detectable in the present, while we would not expect a future from "want" to express the same. However, futures derived from desire verbs are attested with specifically immediate future meaning (Heine

48. Translocative verbs are not necessarily the only source for prospectives, however. Wolvengrey $(2006: 399, \mathrm{n} .4)$ states that the Cree prospective marker $w \hat{\imath}$ - "cannot likely be related to a verb of motion" and suggests an adverb meaning "soon" as a possible source for it (note that $w \hat{i}$ - is indeed a marker of the general prospective rather than the immediate future, as one might expect if it is derived from such an adverb). 
\& Kuteva 2002:311-313, ${ }^{49}$ Bybee, Perkins \& Pagliuca 1994:254), which has been categorized as a type of prospective aspect (Comrie 1976:64). They are not attested in the above samples with general prospective meaning, however, so it may be that immediate futures, despite their connection in meaning, can be grammaticalized from different sources to general prospectives.

\subsubsection{The role of age in future grams}

Another factor behind the functions of $z i(l)$ - may be its relative youth. Verbs of going do also develop into futures that are not prospective..$^{50}$ These come further along the cline of development. It may be that $z i(l)$-would become a true future tense further down the road. It is of significance here that the $b$-future, which is older, has later-developing meanings. The $z i(l)$-future, on the other hand, is still a prospective, in keeping with its origins in a translocative verb, rather than a true future tense.

English provides an excellent case for comparison, as it has two futures derived respectively from a verb of desire and a verb of going. As in the Mosul Plain dialects, the desire future will is the older gram, dating at least as far back as the 14th century (Bybee \& Pagliuca 1987:112-114) ${ }^{51}$ while the going to future is newer, having developed the more figurative sense of progress towards a goal only in the seventeenth century (Bybee \& Pagliuca 1987: 116-117, cf. Traugott 1995:34-36)..$^{52}$ As Bybee \& Pagliuca (1987:116) point out, "The going to construction in English is much younger than shall and will and has not undergone as much semantic change and development." We will examine this second claim on the basis of the stages of semantic development of future grams (FUTAGES) proposed by Bybee, Pagliuca \& Perkins (1991). These stages are mostly defined by the retention or not of original or early functions of the grams (such as desire, intention etc.):

49. Heine \& Kuteva call it 'proximative', and translate most of the examples with the English be about to construction.

50. The distinction is not always made, and many constructions termed 'future' may actually be prospectives. Nevertheless, Bybee, Perkins \& Pagliuca (1994:267-268) give an example (in Zuni) of a 'go'-future which can be used in an apodosis: a late-developing use, typical of true futures rather than prospectives.

51. Bybee \& Pagliuca give an example of will expressing prediction rather than desire (with an inanimate subject) from the text Sir Gawain and the Green Knight, which dates to the late 14th century.

52. Another parallel can be found in Levantine Arabic, where in addition to the rah-future, the pseudo-verb "to want" (bidd-) may also have a future function (Elihay 2006:84, Cowell 1964:347-348). In this case, however, the desire future construction, which is still fully inflected, appears to be younger than the "go"-futurire. 
Table 5. (from Bybee, Pagliuca \& Perkins 1991:32)

\begin{tabular}{llll}
\hline FUTAGE 1 & FUTAGE 2 & FUTAGE 3 & FUTAGE 4 \\
\hline obligation & intention & future & probability \\
desire & root possibility & & possibility \\
ability & immediate future & & imperative \\
& & use in complements \\
& & & use in protases \\
\hline
\end{tabular}

On the face of it English will and going to are both at the second stage of development, FUTAGE 2, as they each still retain earlier uses connected to their sources: intention in both cases, also willingness in the case of will (Bybee, Pagliuca \& Perkins 1991:26) and current relevance in the case of going to. The next stage, FUTAGE 3, is defined as having future as its only use. This applies to neither. Nevertheless there are differences between the two, suggesting that will is further developed than going to.

One sign is that will has acquired a late-developing use of expressing epistemic modality (probability, FUTAGE 4, see Celle 2004), while going to is much less acceptable in this use: ${ }^{53}$

(56) a. (in response to knock on door:) That'll be the postman.

b. 'That's going to be the postman.

Another clue is that will is used in the protasis of conditions, while going to is unusual in this position (Binnick 1971:42, Leech 2004:60, Haegeman 1989:299). The reason is that the present component of going to conflicts with the presence of a future condition (Perez 1990:60). A future event cannot already have its seeds in the present, if it is dependent on a condition in the future. According to Bybee, Perkins \& Pagliuca (1994:274), "apodoses are prime environments for future grams. Apodoses are main clauses where predictions are made that are contingent on the conditions stated in the protasis." Will, therefore, can be used in pure prediction, as a prototypical future, without its other older senses of intention or willingness. Going to, on the other hand, is still inseparable from its older sense of present relevance and cannot be used in pure prediction.

The case in the Mosul Plain dialects is very similar to the situation in English. Both future grams $(z i(l)$ - and $b$-) can be used to express intention:

53. Traugott (1995:35) gives an example of the going to future with such a function, which suggests the beginning of a change: "An accident has been reported on Crockett Boulevard. - That is going to be South of Crockett." 
(57)
a. $z i-n \quad z \bar{a}-l i$. (Alqosh)
PRSP-S.1s go-L.1s
"I'm going to go."
b. 'ānn lá-zi-axl-an wal $d-\bar{a} \theta a \quad l$-betb. (Telkepe)
I NEG-PRSP-eat-S.1Fs until that-come.3Ms to-house
"I'm not going to eat until he comes home."
c. b-dair-an. (Alqosh)
FUT-return-S.1Fs
"I'll come back."
d. 'ānv bd-oð-ən-na. (Telkepe)
I FUT-do-S.1Ms-L.3MS
"I wILL do it!"

Like will, the $b$-future can be used for epistemic modality: ${ }^{54}$
a. 'āyi pt-āwa mar-barid! (Telkepe)
this Fut-be.3MS DERIV.PREF-post
"That'll be the postman!"
b. pt-āwa toma. (Baqopa)
FuT-be.3ms Thomas
"It'll be Thomas."
c. mar-barid pt-āwa. (Alqosh)
DERIV.PREF-post FUT-be.3Ms
"It'll be the postman."

Baqopa and Alqosh speakers did not allow the same function with the $z i(l)$-auxiliary, but speakers from Telkepe and Karimlesh judged it to be acceptable, suggesting the gram in these dialects is more mature.

Like will, the $b$-future is also used in apodoses of conditions:

(59) a. 'an bxe-lux, b-qațl-an-nux. (Telkepe)

if cried-L.2Ms FUT-kill-S.1Ms-L.2Ms

"If you cry I will kill you."

b. 'on $\theta e-l a \quad b-x \bar{a} z-\partial x$-la. (Alqosh)

if came-L.3Ms FuT-see-S.1PL-L.3Ms

"If he comes, we'll see him."

The $z i(l)$-construction in Alqosh, on the other hand, is not allowed in the same circumstances:

54. This is based on data from all dialects except Batnaya, where the speaker did not recognize the usage. 


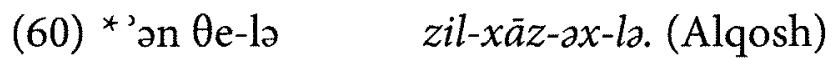

$$
\begin{aligned}
& \text { if came-L.3MS PRSP-see-S.1PL-L.3MS } \\
& \text { "If he comes, we're going to see him." }
\end{aligned}
$$

There are signs that this restriction may relax. In English going to may be used in certain conditionals where there is a grounding in the present (Leech 2004:60, Haegeman 1989:299, 307, Perez 1990:60). In Alqosh, Telkepe and Karimlesh (if not others), $z i(l)$-can be used in an apodosis in the same circumstances:
a. 'on la-mien-at-ti, $\quad z i-n \quad m e \theta$-ən. (Alqosh)
if NEG-help-S.2Ms-L.1s PRSP-S.1s die-S.1MS
"If you don't help me, I'm going to die."
b. 'on la-zon-at-ta, zi-lo zā-la! (Telkepe)
if NEG-buy-S.2MS-L.3MS PRSP-L.3MS go-L.3MS
"If you don't buy it (now), it's going to go."

In example (b), for instance, the characteristics which make the item so saleable exist in the present. It is already on course to being sold, so the prospective can be used.

If this use in apodoses is expanded to cases with no present grounding, then a prospective may turn into a true future tense. This development can be seen in Kru languages that have a 'go'-future. In several the 'go'-future cannot yet occur in the apodosis of a conditional, while in others this shift has taken place (Marchese 1986: 103). In Hausa dialects the same change is taking place in the $z \hat{a} a$ prospective. It is only permitted in apodoses (or other irrealis contexts), however, in its most highly grammaticalized form (Abdoulaye 1999:28-29), further evidence that this is a late development.

Although in most of the dialects the $b$-future is normally offered in translation of apodoses of future conditions, the $z i(l)$ - construction was also judged permissible by informants from Telkepe, Bațnaya, Baqopa and Karimlesh (but not Alqosh), indicating that this loosening is already taking place:

Another sign of the relative youth of $z i(l)$ - is that in at least one dialect (Alqosh) it may still retain the original meaning of translocation, even when formally identical to the auxiliary construction. Some examples were found in an Alqosh children's story that showed this ambiguity. They are all of the following type:

(63) 'ämar-wa zi-n 'amr-an ta'aqubra d-ä $\theta$ a
say.3Ms-PST go.IMM-S.1s/PRSP-S.1s say-S.1Ms to mouse that-come.3Ms 
qāraț-lux.

bite.3Ms-L.2Ms

"He said, 'I'm going to tell the mouse to come and bite you."'

'ämor-wa si!

say.3MS-PST go.IMP.MS

"(The rope) said, 'Go!"”

zal-la mera wo 'aqubra!

went-L.3Ms said:L.3Ms hey mouse

"He went and said, 'Hey Mouse!"”

The context suggests that the statement zin'amron "I'm going to say" does imply actual movement (despite the absence of the purpose marker ta $d$ - "in order"): the mouse responds to this statement by telling him to go, and then he does in fact go. Such cases exist alongside other, unambiguous cases, such as the following, where a lexical reading of $z$ in would render it redundant:

(64) $z i-n \quad z \bar{a}-l i$. (Alqosh)

PRSP-S.1s go-L.1s

"I'm going to go."

The usage with the original meaning of movement would suggest a classification of $z i(l)$-, in Alqosh at least, as FUTAGE 1. Bybee, Pagliuca \& Perkins (1991:26) do not define FUTAGE 1 for future grams from movement verbs, but they do allocate to it futures that retain meanings of desire, obligation and ability, i.e. the very earliest functions of the grams. By analogy, we would expect a translocative function in a 'go'-future to mark it as FUTAGE 1 . By contrast the $b$-future cannot express its original meaning of desire, even if the weaker related meaning of willingness is still possible. The stages of semantic development (FUTAGES) proposed by Bybee, Pagliuca \& Perkins (1991), though useful, throw up some problems with the NeoAramaic case, and perhaps more generally.

All future grams by definition have prediction as a use in addition to any other uses. The differences in FUTAGE are therefore defined by the earliest-developing use that has been retained (FUTAGE 1 and 2) or by the most late-developing use (FUTAGE 4). FUTAGE 3 (future only) is defined by having neither earlier nor later functions. If a gram had the characteristics of both FUTAGE 1 and 2, or of both FUTAGE 2 and 4, it would not be clear how it should be categorized. Alqosh $z i(l)$-in fact can express both translocation (F. 1) and intention (F. 2), while Telkepe $z i(l)$-can express intention (F. 2) and probability (F. 4). The system also does not account for the distinction between the future functions of $z i(l)$-/going to and $b$-/will: in the latter the future time reference can stand alone, while in the former it is yoked to the component of present relevance, a relic of an earlier stage. 
The FUTAGE system does not take into account these differences in their future functions.

The FUTAGES as defined may be more useful for categorizing the relative age of the different functions, rather than of the actual grams. Functions from two or more different stages may co-exist in some cases, and both innovation and conservatism have to be taken into account in judging the maturity of a construction, making the degree of maturity of a given gram difficult to define with precision.

\subsubsection{Can a 'go'-future auxiliary derive from something other than an imperfective form?}

We have established that the prospective meaning of $z i(l)$ - is due to its origin in a translocative verb, as well as the relative youth of the construction such that it has not yet become a marker of pure prediction like the $b$-future. What is surprising in the Neo-Aramaic case, however, is that the $z i(l)$-auxiliary/particle derives from a form functioning not as an imperfective but either as a present perfect or immediate future. Bybee \& Pagliuca (1987:116-117), in discussing the English going to construction, discuss the prevalence of 'go'-futures from forms with imperfective, progressive or continuous aspect, and argue that the progressive aspect of English going to "provides the present orientation sense". Noting that movement verbs also serve as sources for pasts and progressives, Bybee, Pagliuca \& Perkins (1991:30) suggest that imperfectivity is also a necessary condition for development into a future:

... we hypothesize that the semantics of movement is not sufficient in itself to give rise to the future sense. Rather, movement constructions that are sources for future grams actually signal that the subject is in the process of moving towards a goal. That is, along with movement as a component of meaning, the source of such futures includes an imperfective (or progressive) component and an allative component. Neither allativity nor imperfectivity need be overtly marked (as they are, for instance, in the English be going to construction), but we would not expect a motion verb with an ablative component or perfective marking to develop a future reading.

This hypothesis seems to be challenged by the Neo-Aramaic case: $z i(l)$ - does not derive from an imperfective or progressive form, even though such forms are available in the language. Nevertheless, Bybee, Pagliuca \& Perkins' hypothesis, if fine-tuned, does not conflict with the evidence from $z i(l)$-. The reason given for the hypothesis (the subject is in the process of moving towards a goal) does not actually rule out the present perfect or the immediate future prospective. A present perfect of going, such as He has gone to fetch her may have the implicature that he is still en route. The immediate future, I'm just going to fetch her, is said when one is, though not actually already on the road, in the process of preparing to go. 
In both cases, therefore, the subject could be said to be in the process of moving towards a goal.

The use of $z i(l)$ - as an auxiliary is not mentioned in Rhétorés (1912) grammar, so, even if it did exist during his time in Iraq (a little over 100 years ago), it may have been too rare to have come to his attention. It seems therefore to be quite a new construction in the dialects. As $z i(l)$ - apparently already had a non-past (possibly immediate future, cf. \$7.2) function before its development into an auxiliary, it may have been from the immediate future function that the auxiliary developed:

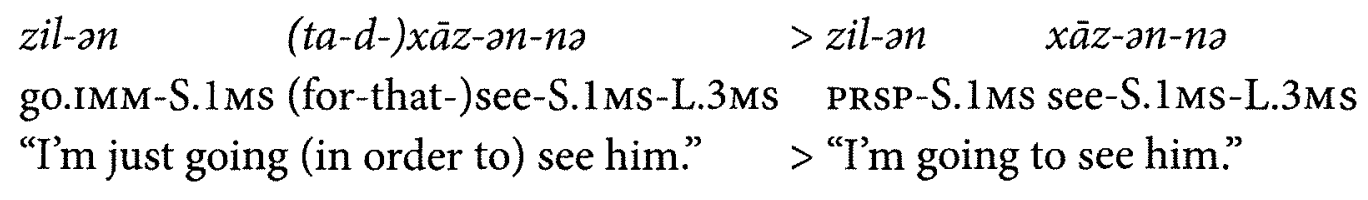

Hausa $z \hat{a} a(\$ 7.4)$ again provides a parallel to this, as the prospective auxiliary is derived, not from a prototypical imperfective or progressive, but from a form used for the immediate future. Abdoulaye (1999:1) noted the "particularity" of the Hausa case, but the Neo-Aramaic case demonstrates that it is not unique.

\subsubsection{The development of the past prospective}

Initially $z i(l)$ - would have developed as an auxiliary for the present prospective. One might expect a past prospective to be based on a past tense equivalent of $z i(l)$-, such as ${ }^{\star}$ zil-S-wa [zil-s-PST]. The suffix -wa (-wä- before suffixes) is the normal means in NENA for shifting past base forms (further) into the past. In Telkepe and Baqopa, however, the strategy is to mark past time reference only on the main verb:

(66) $z i-l o$ 'ä $\theta e-w v$. (Telkepe)

PRSP-L.3MS come.3MS-PST

"He was going to come."

In Karimlesh, however, past time reference is also marked on the auxiliary, which is $z i-w \bar{a}-\mathrm{L}$ (inflected only with L-suffixes), by analogy with present prospective $z i-\mathrm{L}:{ }^{55}$
(67) $z \dot{i}-w \bar{a}-l a$
'à $\theta e-w a$.
PRSP-PST-L.3MS come.3MS-PST
"He was going to come."

55. The position of the past marker $-w \hat{a}$ - before the L-suffix is regular. The same order is found in remote past verbs, e.g. $\theta e-w \bar{a}-l a$ [came-PsT-L.3Ms] "he came (a long time ago)" and in expressions for past possession, e.g. ' $\partial \theta$-wa-li [there.is-PST-L.1s] "I had". Where there are S-suffixes, on the other hand, the past marker follows them, e.g. $k$-palx- $\bar{a}-w v$ [IND.PRS-work-S.3Fs-PST] "she used to work". 
The same construction is used by a Tisqopa speaker, even though the present prospective in that dialect has a mixed $z i$-S/L paradigm. It is possible that past marking on the auxiliary was originally the strategy in Telkepe and Baqopa as well, but as double marking was redundant, the present prospective auxiliary spread to the past prospective as well.

\subsection{The role of influence from Arabic}

The vernacular Arabic prospective particle rah- has already been mentioned, with examples from the well-documented Syrian dialect (\$7.7.1). In fact this particle is also found in Iraqi Arabic. It is documented in the Baghdadi dialect (Erwin 1963:138), ${ }^{56}$ but is also found in the dialect of the city of Mosul (p.c. from native speaker), which is situated very close to the villages where the Mosul Plain dialects are spoken. As $z i(l)$-is only found in NENA dialects in the vicinity of Mosul, and not attested further north or east where Kurdish dominates, it is very likely that its appearance is due at least in part to the influence of the local Arabic dialect. English may provide another parallel. The English 'go'-future may have developed at least partially through influence from French during the Middle English period (Danchev \& Kytö 2002), who note similar futures in German and Dutch dialects in contact with French.

\section{Historical development of $z i(l)$ - forms}

The syntactic and functional changes in $z i(l)$ - have been accompanied by various kinds of changes in form, which will be discussed in this section.

8.1 Changes common to the lexical verb and the auxiliary

Some formal changes in $z i(l)$ - are shared by both the lexical verb and the auxiliary.

\subsubsection{Spread of $z i$ - $L$ through the paradigm}

While $z i(l)$ - clearly derives historically from $z i l-+S$-suffixes, it is apparent from the paradigms of the dialects that, outside Alqosh, this is no longer the synchronic analysis. In Karimlesh, at one extreme, the form has been completely reanalysed as $z i-+\mathrm{L}$-suffixes. In Table 4, we saw from left to right the different stages of reanalysis of $z i l+\mathrm{S}$-suffixes to $z i-+\mathrm{L}$-suffixes. This reanalysis probably took place first in 
the third person forms. As shown in $\$ 6.1,3$ fs. zilv can be analysed as inflected with either an S-suffix or an L-suffix:

(68) 3fs. $z i l v=z i l-b(z i l-\mathrm{S})$ or $z i-l v(z i-\mathrm{L})$

Furthermore $3 \mathrm{~ms}$. $z i l-\varnothing$ could have been reanalysed as $z i l-\partial$, as an $/ \partial /$ would normally be elided before a word starting in a single consonant:
a. $\theta e-l$. (Telkepe/Alqosh)
came-L.3Ms
"He came."
b. $\theta e-l(\partial) \quad$ tammal. ${ }^{57}$
came-L.3Ms yesterday
"He came yesterday."

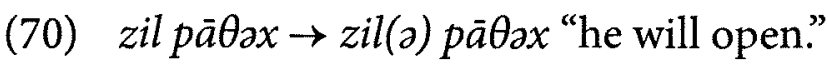

Once this reanalysis had taken place, then the $3 \mathrm{~ms}$. and $3 \mathrm{fs}$. inflections appeared to follow those of the L-suffixes. Then $3 \mathrm{pl}$. ${ }^{*}$ zili was replaced by ${ }^{*}$ zila to bring it into line with the others. This is the stage reached in Tisqopa, Baqopa, Batnaya and Telkepe, where all the 3 rd person suffixes can be analysed as $z i$-L. In Karimlesh this reanalysis has spread to the whole paradigm, so that all forms are based on this analysis.

Analogy must have played a role in this: there are several verbal and pseudoverbal forms in the language which inflect with L-suffixes. The most prominent is the past perfective PAST-L, e.g. šqal-li "I took". Another is the predicate of possession: ' $\partial \theta-\mathrm{L}$, e.g. ' $\partial t-t i$ "I have" (with assimilation), ' $\partial \theta-w \bar{a}-l i$ "I had". Even more relevant may be the irregular present-future base inflection of ' $z l$ found in the Mosul Plain dialects, which is usually formed on $z \bar{a}$-L, e.g. 1 s. $z \bar{a}$ - $l i$, rather than ' $\bar{a} z-\mathrm{S}$ as is found in dialects further north. Therefore there were clear precedents for (pseudo-)verbal forms with this inflection.

\subsubsection{Phonological reduction of forms}

A change that has apparently only occurred in Alqosh ${ }^{58}$ is the reduction of the first person forms: $1 \mathrm{~ms}$. zilan and 1fs. zilan are both reduced to zin, while 1pl. zilax is reduced to zix. These reduced forms exist alongside the longer forms. As Alqosh does not possess second person forms, we cannot see if these too would have been

57. "( )" brackets indicate that the vowel is elided.

58. It is not accepted in Telkepe, Baqopa, or Bațaya, and is not applicable to Karimlesh 1s. $z i$-li. A case of 1 pl. zix was noted down from a Tisqopa speaker's speech several years ago, but another informant consulted recently did not use this form or accept it as a Tisqopa usage. 
reduced. Similar optional reductions are found with the Alqosh 'deictic copula' (1 $\mathrm{ms}$. wowan $/ 1$ fs. wowan $>1$ s. won, $2 \mathrm{~ms}$. wowat $/ 2 \mathrm{fs}$. wowat $>2$ s. wot, $1 \mathrm{pl}$. wowax $>$ wox). ${ }^{59}$

One might expect this reduction to be restricted to auxiliaries, i.e. to occur as a consequence of grammaticalization. Marchese (1986:112-113) cites examples where phonological reduction has occurred in the auxiliary while being unacceptable in the lexical verb from which it is derived. For instance, English gonna can only be used to replace going to in its auxiliary function, not in its lexical sense:

(71) I'm going to the store./*'m gonna the store.

Marchese also cites a similar split in the 'go'-future of Tepo and Grebo.

In the case of Alqosh, however, the phonological reduction is also found with the lexical verb:
(72) $z i-n$
l-bagdad.
go.ImM-S.1s to-Baghdad
"I'm going to Baghdad."

The difference may be due to the fact that the immediate future zil-S construction is a unique verb form restricted to this lexeme. There are no other existing forms which might exert pressure on it to conform to the standard paradigm. In English, by comparison, to be going to, as a lexical verb, is formed like any other present continuous verb, and the existence of other present continuous forms may exert pressure on it not to change. In the Neo-Aramaic case the form is free to drift, without causing any further irregularity. No doubt this uniqueness also facilitated the reanalysis in other dialects from $z i l-\mathrm{S}$ to $z i(l)-\mathrm{S} / \mathrm{L}$, then $z i$-L. The various formal changes may have occurred after grammaticalization as an auxiliary, then spread to the lexical verb. Or quite possibly they may have occurred independently of the auxiliarization process, through unrelated phonological erosion. ${ }^{60}$

\subsection{The formal development of the prospective construction}

\subsubsection{The formal development of the auxiliary construction ${ }^{61}$}

According to the explanation given in $\$ 7.7$, we may understand the $z i(l)$-auxiliary construction to derive from a finite lexical verb form followed by a purpose clause.

59. Similar reductions are also found in forms in other dialects, as, for example, in the Telkepe present copula: $2 \mathrm{~ms}$.' iwat, $2 \mathrm{fs}$. 'iwat $>2$ s. 'it. etc.

6o. Marchese (1986: 114), in her discussion of Kru futures, also makes the point that phonological reduction associated with an auxiliary is not necessarily linked to the grammaticalization process.

61. Neo-Aramaic examples in this section are from the Telkepe dialect. 
Purpose clauses in the current spoken language are formed from the unprefixed inflected present-future base ('subjunctive') of the verb, preceded by the particle $t a$ and the complementizer $d$-. (Note that the subjunctive has various irrealis functions):

$$
\begin{aligned}
& \text { (73) zal-li ta-d-xāz-an-no } \\
& \text { went-L.1s for-that-see-S.1Ms-L.3Fs } \\
& \text { "I went (in order) to see her." }
\end{aligned}
$$

We might therefore expect $z i l-a n$ as an auxiliary to derive from the following type of structure (which is grammatical as a purpose clause in the modern dialect):

$$
\begin{aligned}
& \text { (74) } z i l \text {-ən ta- } d-x \bar{a} z-\partial n-n v \\
& \text { go.IMM-S.1Ms for-that-see-S.1Ms-L.3FS } \\
& \text { "I'm just going (in order) to see her." }
\end{aligned}
$$

What we actually find is the subjunctive without the purpose marker $t a-d$-:

$$
\begin{aligned}
& \text { (75) } z i l-ə n \quad x \bar{z} z-\supset n-n v \\
& \text { go.IMM-S.1Ms see-S.1Ms-L.3Fs } \\
& \text { "I'm going to see her." (prospective) }
\end{aligned}
$$

We may also compare $z i(l)$ - to the various verbs and expressions with modal or similar meaning which take irrealis complement clauses. These take the subjunctive preceded by the complementizer $d$-:

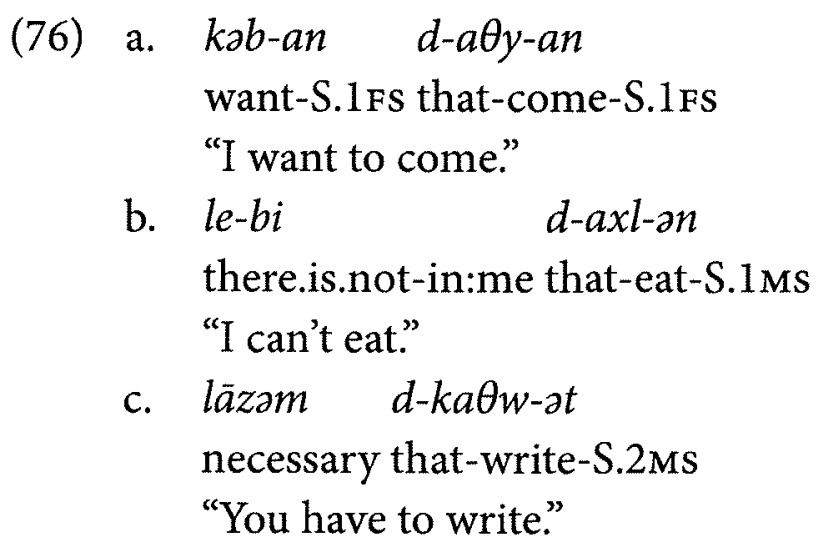

It is significant, however, that expressions of ability and necessity (as in 76b, c) are attested sometimes without the complementizer:
a. 'i-boxu $k a \theta w-\bar{u} t u$
there.is-in:you.PL write-S.2PL
"You can write."
b. lāzam yālap necessary learn.3Ms
"He has to learn." 
The $z i(l)$ - auxiliary construction, like many other auxiliary constructions, began as a biclausal structure (Harris \& Campbell 1995:172-191, Anderson 2006:320321): a main clause followed by a purpose clause (perhaps preceded by a purpose marker such as $t a d$-). Then, as $z i(l)$ - was reanalyzed as an auxiliary in a monoclausal construction, with aspectual rather than lexical function, it took on a closer syntactic connection to the lexical verb, possibly with less explicit marking of the relationship. It may be that there was a stage of marking the lexical verb as a complement by means of the complementizer $d$-, as occurs with the modal + complement constructions described above. Anderson (2006) writes as follows of clause combining in auxiliaries:

... the semantic connection between the verbal elements may be one of purpose or manner, with one verb representing the purpose or manner action, the other usually a motion verb logically preceding and performed specifically to manifest the purpose of the event, or accompanied by the manner of the event, embodied in the verb encoding that purpose/manner. This purpose- or manner-encoding verb may be marked by a morphological index that is also found in verb-complement structures. (Anderson 2006:319)

If the lexical verb was indeed marked by $d$-, this was lost in the next stage of grammaticalization, just as it is now being lost with some of the modal expressions: ${ }^{62}$

zil-an (ta-)d-xāz-ən-nv >zil-ən d-xäzannv >zil-ən xäzənnv

"I'm just going (in order) to see her." > "I'm going to see her."

A parallel is found in the development of the Georgian modal verbs (Harris \& Campbell 1995:173-176). Upon reanalysis of a verb of desire to a modal meaning (epistemic necessity or deontic obligation), the construction changed from biclausal to monoclausal and the complementizer was dropped (while being retained in the ungrammaticalized construction which continued to be used).

Some parallels to the process of auxiliarization can be found in the Levantine Arabic construction räyih/rah- (\$7.7.1). In Arabic too, the auxiliary or particle is combined with a verb in the subjunctive (similar in functions to the NENA subjunctive), in the same way that verbs of wanting and ability combine (compare examples (a)-(c)). As in NENA the irrealis form is the unprefixed verb: for comparison, the (prefixed) indicative form can be seen in example (d) below:

62. This is not, however, a necessary part of the grammaticalization process. According to the proposed reconstructions of the other future prefix bad-given in $\$ 3.1$, the complementizer has been retained and absorbed into the prefix: ${ }^{\star} k a b a / b \bar{a} e / b \bar{e} d$-šăqal [he.wants/it.is.desired thattake.3Ms] "he wants to take" > bod-šagal [FuT-take.3Ms] "he will take". 
(78)

a. $r a \bar{y} y-i ̣ n / r a h$ tibu.

going.PTCP-PL/PRSP stay.2PL

"You are (pl.) going to stay."

b. bidd-kom tibu.

want-2PL stay.2PL

"You want to stay."

c. b-tiqdaru tibu

IND-be.able.2PL stay.2PL

"You can stay."

d. $b$-tibu.

IND-stay.2PL

"You stay."

Purpose clauses, on the other hand, require a special particle, rather than the subjunctive alone:

(79) jït maxșūss 'ašān 'ašūf-ak. (Elihay 2006:21)

came:1s specially in.order.that see.1s-you.Ms

"I came specially to see you."

The parallel between Levantine Arabic rah- and NENA $z i(l)$ - is not exact, as in Levantine Arabic no complementizer is involved, therefore the issue of its loss does not arise.

Auxiliaries in some languages (namely English and Kru languages) show distinct syntactic behaviour from full verbs (Lightfoot 1974, Marchese 1986:77-82). Although some of the characteristics of the English and Kru cases are not applicable to Neo-Aramaic, there is evidence for both similarity and difference. The auxiliary $z i(l)$ - inflects for person (though a non-inflected particle also exists in some dialects). However, unlike full verbs, it is not inflected for tense or aspect (except in Karimlesh/Tisqopa where two tenses are distinguished):

(80) zi-la 'āAe-wo. (Telkepe/Baqopa)

PRSP-L.3MS come.3MS-PST

"He was going to come."

\subsubsection{The development from an auxiliary to a particle}

The other main formal development is the emergence of a fossilized particle (zil-/ $z i-/ s i-)$, derived from the $3 \mathrm{~ms}$. form, as is found in Telkepe, Tisqopa and (through recent borrowing) Alqosh, but not in Baqopa, Bațnaya or Karimlesh. It is common in grammaticalization for one inflection to spread throughout the paradigm. In Telkepe and Tisqopa the particle has also become phonetically eroded to $z i$ ( $s i$ - in the case of one young speaker). Erosion is also common in processes of 
morphologization (Hopper \& Traugott 1993:145-150). In the case of auxiliarization, erosion would be expected to follow the stage of clause fusion and the change from lexical to grammatical function (Harris \& Campbell 1995: 194), as is indeed the case here. A similar example of loss of inflection and phonetic reduction has already been mentioned: the development of the vernacular Arabic future particle rah-from the inflected participle räyih.

It is also not unusual for two stages of formal grammaticalization to co-exist synchronically. Anderson (2006:377-384) presents examples of fused and unfused forms of auxiliaries co-existing, as also of auxiliaries being used in both inflected and uninflected forms. In the Mosul Plain we have a fused uninflected form zil(or partially eroded $z i$-) co-existing with the older unfused inflected auxiliary $z i(l)$ S/L.

\section{Summary of developments}

Various attributes have been discussed above which indicate the relative maturity of $z i(l)$ - both as an independent verb and as an auxiliary. These can help us understand in which dialects $z i(l)$ - is more mature.

First, three attributes mark the maturity of the development from a pragmatic use of the past for immediate future to a dedicated immediate future form. One of these attributes is the loss of past time reference (still found at the time of Rhétoré, $\$ 7.2$ ), which all Mosul Plain dialects have now lost. Another is the extension of the construction to non-first person subjects, in Tisqopa, Baqopa, Bațaya and Telkepe. Finally, negation is permitted, which has only occurred in Tisqopa, Baqopa and Telkepe. These markers of maturity are given in Table 6 below (shaded):

Table 6. Markers of maturity in development of the independent verb

\begin{tabular}{|c|c|c|c|c|c|c|}
\hline & \multicolumn{6}{|c|}{ North $\longrightarrow$ South(-east) } \\
\hline & Alqosh & Tisqopa & Baqopa & Baṭnaya & Telkepe & Karim. \\
\hline $\begin{array}{l}\text { Lost past } \\
\text { time refer- } \\
\text { ence }\end{array}$ & yes: & yes & yes & yes & yes & yes \\
\hline $\begin{array}{l}\text { Used with } \\
\text { 2nd and } \\
\text { 3rd person }\end{array}$ & no & yes & yes & yes & yes & no \\
\hline Negatable & no & yes: & yes & no & yes. & no \\
\hline
\end{tabular}


Judging by these data, the dialects may be ranged in order of less to more maturity of independent $z i(l)-:$ (1) Alqosh, Karimlesh, (2) Baṭnaya, and (3) Tisqopa, Baqopa and Telkepe.

For the development of the auxiliary, more markers of maturity are available, in Table 7. These include use with non-first person subjects, use with inanimate subjects, the development of a past prospective and the negatability of forms. They also include later-developing uses: pure prediction (in the apodosis of a future condition) and epistemic modality. Markers of maturity for Alqosh are in brackets and shaded paler, as they are thought to be only recent borrowings, and so less reliable. One entry for Tisqopa is also shaded pale as the informant was hesitant about this usage.

Table 7. Markers of maturity in grammaticalization of the auxiliary

\begin{tabular}{|c|c|c|c|c|c|c|}
\hline & \multicolumn{6}{|c|}{ North $\longrightarrow$ South(-east) } \\
\hline & Alqosh & Tisqopa & Baqopa & Bațnaya & Telkepe & Karim. \\
\hline $\begin{array}{l}\text { Used with } \\
\text { 2nd and } \\
\text { 3rd person }\end{array}$ & (yes) & yes & yes & yes & yes & yes \\
\hline $\begin{array}{l}\text { Used with } \\
\text { inanimate } \\
\text { subject }\end{array}$ & (yes) & yes & yes & yes & yes & yes \\
\hline $\begin{array}{l}\text { Past pro- } \\
\text { spective } \\
\text { available }\end{array}$ & no & yes. & yes & no & yes & yes \\
\hline $\begin{array}{l}\text { Negatable } \\
\text { (all forms) }\end{array}$ & no & yes & yes & yes & yes & yes \\
\hline $\begin{array}{l}\text { Apodosis } \\
\text { of future } \\
\text { condition }\end{array}$ & no & yes & yes & yes & yes & yes \\
\hline $\begin{array}{l}\text { Epistemic } \\
\text { usage }\end{array}$ & no & yes & no & no & yes & yes \\
\hline $\begin{array}{l}\text { Uninflected } \\
\text { particle } \\
\text { used }\end{array}$ & (yes) & (yes) & no & no & yes & no \\
\hline
\end{tabular}

Judging by this table, Alqosh in the north has the least mature gram. Baqopa and Bațnaya are more mature and at similar stages, except that Batnaya has not developed a past prospective. Telkepe and Karimlesh are further developed in allowing an epistemic modal use of $z i(l)$-. Telkepe, in the south, is more developed formally than Karimlesh in having an uninflected particle as well as an inflected auxiliary. 
Tisqopa is the odd one out, in being almost equally mature to Telkepe although the village is situated close to Alqosh.

Telkepe therefore has the most mature gram, Alqosh the least, and the other dialects fall in between, except perhaps for Tisqopa. The evidence tends to suggest therefore that $z i(l)$ - began in Telkepe then diffused north and east to the other dialects: the dialects which have adopted it more recently might be expected to show less mature grammaticalization. Only Tisqopa does not fit this model.

Some caveats must be borne in mind. First, the grammaticalization may have occurred at a faster pace in some dialects than in others, and this, rather than greater time depth, could account for the maturity of the grammaticalization process. Second, the dialects are in constant contact with each other, and some speakers may be influenced by the more advanced usage of the forms in another dialect, as was suggested by one Alqoshi regarding use with 2nd or 3rd person subjects. Third, the data is drawn from only one or two speakers per dialect (though more in Telkepe), depending on availability. The slightly puzzling data from Tisqopa was gathered from only one informant. The speakers also come from different generations: in Telkepe the two youngest informants (in their 20s and 30s) were recorded only using the particle, which the youngest pronounced as $s i-$, rather than $z i$ - like his elders. There may therefore be new changes occurring in the speech of the younger generation. In addition, there may be idiolectal differences caused by the different migrational histories of informants (all data was from speakers outside Iraq). While the data cannot be taken as representative of all speakers of a dialect, given the relative uniformity within individual villages in other aspects of the language, we would expect only minor differences, but even these might affect the ranking, if larger sampling were possible.

Nevertheless the hypothesis that the form originated in Telkepe and diffused north and east has other support: if $z i(l)$ - has indeed arisen as a result of pattern borrowing from Arabic rah-, it is significant that Telkepe is the village closest to Mosul, where Arabic is spoken. At the very least, we can rule out Alqosh or Karimlesh as the origin, both being on the fringes of the area where $z i(l)$-is used. Alqosh is even more unlikely given that virtually all markers of maturity are lacking in the data available.

The following table shows a summary of the historical development of $z i(l)$ in the Mosul Plain dialects. Note that some stages have only taken place in some dialects. Also, many of the different stages co-exist within a single dialect, such as the functions of independent verb, auxiliary and particle.

Gaps between grammaticalization chains indicate that overlap is possible: for instance $z i(l)$-could begin its development as an auxiliary before it became negatable as an independent verb (as happened in Alqosh). 
Table 8: Historical development of $z i(l)$ -

A. Grammaticalization of $z i(l)$ -

As an independent verb:

$\rightarrow$ acquiring immediate future function

zilan "I have gone." $\rightarrow$ "I'm just going/ about to go."

$\rightarrow$ spreads to 2 nd and 3 rd person

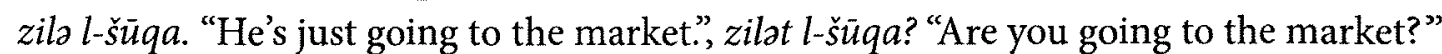

$\rightarrow$ becomes negatable

lá-zilan l-šùqa. "I'm not going to the market."

As an auxiliary verb:

$\rightarrow$ used in a purposive construction:

zilan (ta-)d-šaqlan "I am just going (in order) to take."

$\rightarrow$ reanalysed as prospective auxiliary, complementizer lost, with optional sense of movement

zilan šaqlan "I'm going to take."

$\rightarrow$ reanalysed as pure prospective auxiliary, no sense of movement zilan zäli "I'm going to go."

$\rightarrow$ used also for pure prediction (e.g. in apodosis of future condition) 'on $\theta e l$, zilux xäzuxla. "If he comes, we'll see him."

$\rightarrow$ develops late-developing epistemic use zila häwa toma. "It'll be Thomas."

As a particle:

$\rightarrow$ prospective particle $z i l$ - inflected $\rightarrow 3 \mathrm{~ms}$. $z i l$ - spreads throughout paradigm

$\rightarrow$ phonetically reduced particle $z i l-\rightarrow z i-$ and $s i-$

B. Parallel development of the forms (both independent and auxiliary verb) Reduction of forms

1ms. $z i l-a n / 1$ fs. $z i l-a n \rightarrow 1$ s. $z i-n$, and 1pl. $z i l-a x \rightarrow z i-x$ (Alqosh)

Reanalysis of inflection

3fs. $z i l-a(z i l-\mathrm{S}) \rightarrow z i-l a(z i-\mathrm{L})$

$\rightarrow 3 \mathrm{~ms}, 3 \mathrm{pl} z i l-\mathrm{S} \rightarrow z i-\mathrm{L}$ (all dialects but Alqosh)

$\rightarrow z i$-L spreads to whole paradigm (Karimlesh)

\section{Conclusions}

The historical development of $z i(l)$ - in the Mosul Plain dialects casts light on several grammaticalization processes. First, it serves as an (apparently rare) example of the grammaticalization of a pragmatic use of a past tense form to express 
immediate future. As shown ( $\$ 7.3$ ), this pragmatic use of a past tense (or perfective) with verbs of translocation in the first person is common cross-linguistically: it seems the past tense is used to assert the certainty of the event. In Neo-Aramaic, the form used has lost the original past tense function and been specialized for the immediate future usage. It has not, however, developed into a full tense. Although in some dialects its use has been extended to $2 \mathrm{nd}$ and $3 \mathrm{rd}$ persons and also to negated clauses, lexically its distribution has not been broadened beyond the translocative verb' $z l$ " to go".

Second, $z i(l)$ - is a counterexample to the hypothesis (Bybee \& Pagliuca 1987: 116, Bybee, Pagliuca \& Perkins 1991:30) that in futures derived from a verb of motion, the verb will be in an imperfective or progressive form, or at least a form that will cover these functions. The $z i(l)$ - prospective auxiliary/particle derives from a form known to have had two functions: present perfect and immediate future. It does not derive from the available imperfective forms. As shown above (\$7.7.3), however, both present perfect and immediate future functions may also contain the sense of 'progress towards a goal' that is the basis for the grammaticalization of imperfectives into futures. The hypothesis needs therefore to be extended somewhat, rather than abandoned altogether.

It also supports the view (cf. \$7.7.1) that a construction with a translocative verb, through describing a present process leading to an event, naturally develops into a prospective rather than a simple future in the first instance: i.e. one would expect in a less mature gram a present component yoked to the future component. The present component might later be lost, rendering it a simple future tense. Desire futures seem to have less of a tendency to become prospectives (although they do develop into immediate futures). While desire verbs express a present state leading to an event, and thus have a present component, they express a psychological, invisible state, rather than a process which can be observed, as in the case of translocative verbs.

Where two future grams exist, as in the Mosul Plain dialects, distinctions between them are based on an interaction of source and age. Younger grams may retain more original functions related to their lexical source. Older grams may have lost these functions and/or developed more late-developing functions. This is evident in the Mosul Plain dialects, where the younger gram $z i(l)$-retains a prospective function, and is less used than $b$-for late-developing uses, such as pure prediction and epistemic modality. As was shown in $\$ 7.7 .2$, however, the loss of early functions and adoption of new functions are separate processes: one does not necessarily imply the other.

Finally, the evidence $(\$ 7.8)$ points to the $z i(l)$ - prospective being an example of a new tense formed on the model of a contact language (a 'pattern borrowing', cf. Sakel 2007). In this case, the construction seems to have developed first 
in the village closest to the town where Arabic is spoken, then diffused through the neighbouring villages, showing the greatest signs of immaturity in the village furthest away.

\section{References}

Abdoulaye, Mahamane L. 1999. "The grammaticalization of Hausa zâa 'be going' to future". Journal of African Languages and Linguistics 20:1.1-32.

Anderson, Gregory D.S. 2006. Auxiliary Verb Constructions. Oxford: Oxford University Press.

Beg, Mirza K. A. 1988. Urdu Grammar: History and structure. New Delhi: Bahri Publications. (= Series in Indian Languages and Linguistics 18.)

Bhatia, Tej K. 1993. Punjabi: A cognitive-descriptive grammar. London: Routledge.

Binnick, Robert I. 1971. "Will' and 'be going to"'. Proceedings of the 7th Regional Meeting Chicago Linguistic Society 7.40-52.

Binnick, Robert I. 1972. "Will' and 'be going to' II". Proceedings of the 8th Regional Meeting Chicago Linguistic Society 8.3-9.

Borg, Albert J. \& Marie Azzopardi-Alexander. 1996. Maltese. London: Routledge.

Borghero, Roberta. 2008. "The verbal system of the Neo-Aramaic dialect of Karimlesh". NeoAramaic Dialect Studies ed. by Geoffrey Khan, 81-89. Piscataway: Gorgias.

Bybee, Joan \& William Pagliuca. 1987. "The evolution of future meaning”. Papers from the 7th International Conference on Historical Linguistics ed. by Anna Giacalone Ramat, Onofrio Carruba \& Giuliano Bernini, 109-122. Amsterdam: John Benjamins.

Bybee, Joan, William Pagliuca \& Revere Perkins. 1991. "Back to the future". Approaches to Grammaticalization, vol. II ed. by Elizabeth Closs Traugott \& Bernd Heine, 17-58. Amsterdam: John Benjamins.

Bybee, Joan, Revere Perkins \& William Pagliuca. 1994. The Evolution of Grammar: Tense, aspect and modality in the languages of the world. Chicago: Chicago University Press.

Celle, Agnès. 2004. "The French future tense and English will as markers of epistemic modality". Languages in Contrast 5:2.181-218.

Coghill, Eleanor \& Guy Deutscher. 2002. "The origin of ergativity in Sumerian, and the 'inversion' in pronominal agreement: a historical explanation based on Neo-Aramaic parallels". Orientalia 71:3.267-290.

Comrie, Bernard. 1976. Aspect. Cambridge: Cambridge University Press.

Comrie, Bernard. 1985. Tense. Cambridge: Cambridge University Press.

Cowell, Mark W. 1964. Reference Grammar of Syrian Arabic: Based on the dialect of Damascus. Washington D.C.: Georgetown University Press. (= Richard Slade Harrell Arabic Series 6.)

Craig, Colette G. 1991. "Ways to go in Rama: A case study in polygrammaticalization". Approaches to grammaticalization, Volume II, ed. by Elizabeth Closs Traugott \& Bernd Heine, 455-492. Amsterdam: John Benjamins.

Dahl, Östen. 1985. Tense and Aspect Systems. Oxford: Blackwell.

Danchev, Andrei \& Merja Kytö. 2002. "The go-futures in English and French viewed as an areal feature". North-western European Language Evolution 40.29-60.

Dik, Simon C. 1997. The Theory of Functional Grammar: Part 1. 2nd ed. by Kees Hengeveld. Berlin: Mouton de Gruyter. 
Duval, Rubens. 1881. Traité de grammaire syriaque. Paris: F. Vieweg.

Ebert, Karen H. 2000. "Aspect in Maltese". Tense and aspect in the languages of Europe ed. by Östen Dahl, 753-785. Berlin: de Gruyter.

Elihay, J. 2006. The Olive Tree Dictionary: A transliterated dictionary of conversational Eastern Arabic (Palestinian). Jerusalem: Minerva Instruction \& Consultation.

Erwin, Wallace M. 1963, republished 2004. A Short Reference Grammar of Iraqi Arabic. Washington D.C.: Georgetown University Press.

Garbell, Irene. 1965. The Jewish Neo-Aramaic dialect of Persian Azerbaijan: Linguistic analysis and folkloristic texts. The Hague: Mouton.

Goldenberg, Gideon. 1992. “Aramaic perfects”. Israel Oriental Studies 12.113-137.

Haegeman, Liliane. 1989. "'Be going to' and 'will': A pragmatic account". Linguistics 25.291317.

Heine, Bernd \& Tania Kuteva. 2002. World Lexicon of Grammaticalization. Cambridge: Cambridge University Press.

Harris, Alice C. \& Lyle Campbell. 1995. Historical Syntax in Cross-Linguistic Perspective. Cambridge: Cambridge University Press.

Hoberman, Robert D. 1988. "The History of the Modern Aramaic Pronouns and Pronominal Suffixes". Journal of the American Oriental Society 108.557-575.

Hoberman, Robert D. 1989. The Syntax and Semantics of Verb Morphology in Modern Aramaic. New Haven, Conn.: American Oriental Society.

Hopper, Paul J. \& Elizabeth Closs Traugott. 1993. Grammaticalization. Cambridge: Cambridge University Press.

Jaggar, Philip J. 2001. Hausa. Amsterdam: John Benjamins. (= London Oriental and African Languages Library 7.)

Jastrow, Otto. 1988. Der Neuaramäische Dialekt von Hertevin (Provinz Siirt). (= Semitica Viva 3.) Wiesbaden: Harrasowitz.

Khan, Geoffrey. 2002. The Neo-Aramaic Dialect of Qaraqosh. Leiden: Brill.

Khan, Geoffrey. 2004. The Jewish Neo-Aramaic Dialect of Sulemaniyya and Halabja. Leiden: Brill. Khan, Geoffrey. 2008a. The Neo-Aramaic Dialect of Barwar. Leiden: Brill.

Khan, Geoffrey. 2008b. The Jewish Neo-Aramaic Dialect of Urmi. Piscataway: Gorgias.

Leech, Geoffrey N. 2004. Meaning and the English Verb. Longmans: London. (Revised edition; original edition 1971.)

Lightfoot, David W. 1974. "The diachronic analysis of English modals". Historical linguistics: Proceedings of the First International Conference on Historical Linguistics ed. by John M. Anderson \& Charles Jones, 219-249. Amsterdam: North Holland.

Maclean, Arthur John. 1895. Grammar of the Dialects of Vernacular Syriac. Cambridge: Cambridge University Press.

Marchese, Lynell. 1986. Tense/Aspect and the Development of Auxiliaries in Kru Languages. Dallas: Summer Institute of Linguistics \& the University of Texas at Arlington. (= SIL: Publications in Linguistics 78.)

McGregor, Ronald Stuart. 1972. Outline of Hindi Grammar with Exercises. Oxford: Clarendon Press.

Mengozzi, Alessandro. 2002. Israel of Alqosh and Joseph of Telkepe, A story in a truthful language: Religious poems in vernacular Syriac (North Iraq, 17th Century), vol. II: Introduction and Translation. Leuven: Peeters. (= Corpos Scriptorum Christianorum Orientalium, 590, Scriptores Syri Tomus 231.)

Moshiri, Leila. 1988. Colloquial Persian. London: Routledge. 
Nöldeke, Theodor. 1904. Compendious Syriac Grammar: Translated from the second German edition by James A. Crichton. London: Williams \& Norgate. (Reprinted 2001 by Eisenbrauns.)

Payne Smith, Jessie (Mrs. Margoliouth). 1902. A Compendious Syriac Dictionary, founded upon the Thesaurus Syriacus of R. Payne Smith, D.D. Oxford: Oxford University Press. (Reprinted 1999 by Wipf \& Stock Publishers.)

Perez, Aveline. 1990. "Time in motion: Grammaticalisation of the be going to construction in English". La Trobe Working Papers in Linguistics 3.49-64.

Rice, Frank A. \& Majed F. Sa'id. 1960. Eastern Arabic. Washington D.C.: Georgetown University Press. (Reprinted 2005.)

Rhétoré, Jacques. 1912. Grammaire de la langue Soureth ou Chaldéen vulgaire, selon le dialecte de la plaine de Mossoul et des pays adjacents. Mossoul: Imprimerie des Pères Dominicains.

Rubin, Aaron D. 2005. Studies in Semitic Grammaticalization. Winona Lake: Eisenbrauns. (= Harvard Semitic Studies 57.)

Sabar, Yona. 1984. Midrashim ba-Aramit Yehude Kurdista'n la-Parashiyot Va-Yehi Be-Shallah,ve Yitro. (= Homilies in the Neo-Aramaic of the Kurdistani Jews on the Parashot Wayhi, Beshallah and Yitro). Jerusalem: Israel Academy of Sciences and Humanities: Section of the Humanities.

Sachau, Eduard. 1895. Skizze des Fellichi-Dialekts von Mosul. (Abhandlungen der Königlichen Preussischen Akademie der Wissenschaften zu Berlin von Jahre 1895.) Berlin: Königliche Akademie der Wissenschaften.

Sakel, Jeanette. 2007. "Types of loan: Matter and pattern". Grammatical borrowing in cross-linguistic perspective ed. by Yaron Matras \& Jeanette Sakel. Berlin: Mouton de Gruyter.

Stoddard, David Tappan. 1855. "Grammar of the Modern Syriac Language, as spoken in Oroomiah, Persiah and Koordistan". Journal of the American Oriental Society 5.1-180.

Tavangar, Manoochehr \& Mohammad Amouzadeh. 2006. "Deictic projection: An inquiry into the future-oriented past tense in Persian". Studia Linguistica 60:1.97-120.

Traugott, Elizabeth Closs. 1995. "Subjectification in grammaticalisation". Subjectivity and subjectivisation: Linguistic perspectives ed. by Dieter Stein \& Susan Wright, 31-54. Cambridge: Cambridge University Press.

Wolvengrey, Arok. 2006. "Prospective aspect in the western dialects of Cree". International Journal of American Linguistics 72:3.397-407.

\section{Résumé}

Ce travail examine le développement d'un auxiliaire du futur (plus précisément "prospectif") émanant d'un verbe translocatif dans un petit group de dialectes néo-araméens parlés en Irak. L'araméen, en raison de sa longue histoire écrite, nous permet de suivre en détail le processus de la grammaticalisation. De plus, la documentation récente des dialectes existants a démontré que les différentes étapes du processus peuvent coexister en synchronie. Le cas du néo-araméen se distingue de celui de langues qui voient apparaître un verbe auxiliaire issu du verbe "aller ", où ce genre d'auxiliaire est supposé dériver d'un imperfectif dans the langues où ce temps existe. Le développement de cet auxiliaire néo-araméen implique aussi la ré-analyse d'un présent en futur proche: dans mon travail on clarifie les origines de ce changement (surprenant à première vue) et on le compare à des cas similaires dans d'autres langues. La construction prospective existe avec une autre forme du futur. La différence de forme et de fonction de ce temps permettent de 
percevoir l'origine et l'âge distincts des deux constructions du futur. Il y a de fortes indications que la construction prospective est apparue en néo-araméen par le biais du contact avec l'arabe vernaculaire, où existe une construction semblable. La distribution et l'âge de la construction dans les différents dialectes tirent leur origine d'un village près d'une zone arabophone. De là on peut établir son parcours et sa diffusion dans les villages avoisinants.

\section{Zusammenfassung}

Dieser Aufsatz untersucht die diachrone Entwicklung eines futuranzeigenden (genauer „prospective"). Hilfsverbs aus einem Bewegungsverb in einigen neuaramäischen Dialekten des Irak. Die weit zurückreichenden schriftlichen Zeugnisse des Aramäischen erlauben es, seinen Grammatikalisierungsprozess recht deutlich nachzuzeichnen. Die jüngere Dokumentation der Dialekte hat außerdem gezeigt, dass verschiedene Entwicklungsstufen dieses Prozesses zeitgleich existierten. Der Fall des Neuaramäischen begründet Zweifel an der Theorie, dass futuranzeigende Bewegungshilfsverben (sog. ,"go'-future auxiliaries“) aus einem Imperfektiv abgeleitet werden, sofern die betreffende Sprache einen solchen kennt. Diese Entwicklung des Hilfsverbs bringt auch die Reanalyse eines Perfekts als unmittelbares Futur mit sich. Diese anscheinend überraschende Entwicklung soll erklärt und Parallelen dazu in anderen Sprachen aufgezeigt werden. Neben dieser („prospective“) Konstruktion besteht eine andere Futurform, wobei sich in den unterschiedlichen Formen und Funktionen die Herkunft und das Alter der jeweiligen Konstruktion widerspiegeln. Es gibt deutliche Hinweise darauf, dass sich das „Prospective“ unter dem Einfluss einer ähnlichen Konstruktion in der arabischen Umgangssprache entwickelt haben könnte. Die Verbreitung und der Entwicklungsgrad der Konstruktion in den verschiedenen Dialekten lässt sich dann dadurch erklären, dass die Konstruktion ihren Ursprung in einem nahe der arabischsprachigen Gebiete gelegenen Dorf hat und sich von dort in angrenzende Dörfer verbreitet hat.

\section{Author's address}

Dr. Eleanor Coghill

Zukunftskolleg

University of Konstanz

Box 216

78457 Konstanz, Germany

eleanor.coghill@uni-konstanz.de 